\title{
Serious Non-AIDS events: Immunopathogenesis and interventional strategies
}

\author{
Denise $\mathrm{C} \mathrm{Hsu}^{1 *}$, Irini Sereti ${ }^{2}$ and Jintanat Ananworanich ${ }^{3}$
}

\begin{abstract}
Despite the major advances in the management of HIV infection, HIV-infected patients still have greater morbidity and mortality than the general population. Serious non-AIDS events (SNAEs), including non-AIDS malignancies, cardiovascular events, renal and hepatic disease, bone disorders and neurocognitive impairment, have become the major causes of morbidity and mortality in the antiretroviral therapy (ART) era. SNAEs occur at the rate of 1 to 2 per 100 person-years of follow-up. The pathogenesis of SNAEs is multifactorial and includes the direct effect of HIV and associated immunodeficiency, underlying co-infections and co-morbidities, immune activation with associated inflammation and coagulopathy as well as ART toxicities. A number of novel strategies such as ART intensification, treatment of co-infection, the use of anti-inflammatory drugs and agents that reduce microbial translocation are currently being examined for their potential effects in reducing immune activation and SNAEs. However, currently, initiation of ART before advanced immunodeficiency, smoking cessation, optimisation of cardiovascular risk factors and treatment of HCV infection are most strongly linked with reduced risk of SNAEs or mortality. Clinicians should therefore focus their attention on addressing these issues prior to the availability of further data.
\end{abstract}

Keywords: Serious non-AIDS events, Immune activation, HIV infection

\section{Introduction}

Since the first description of AIDS in 1981, there have been tremendous advances in understanding the biology of the virus, the host's immune response and the clinical management of HIV infection. The introduction of combination antiretroviral therapy (ART) in 1996 has revolutionized HIV treatment, increasing the average life expectancy after HIV diagnosis from 10.5 to 22.5 years from 1996 to 2005 [1]. The estimated life expectancy for a 30 year old male infected with a drug-sensitive virus in 2010 and starting ART at about 6 years post infection can be as high as 75 years in some predictive models [2].

Despite the success of ART, life expectancy in HIVinfected patients is still lower than uninfected persons [2-4] and mortality in HIV-infected patients can be up to 15 times higher when compared with the general population, matched for sex and age [3]. In the pre-ART era, AIDS was the primary cause of death in HIV-infected patients [5-7]. With the use of ART, mortality due to serious

\footnotetext{
* Correspondence: d.hsu@amr.org.au

${ }^{1}$ The Kirby Institute for Infection and Immunity in Society, University of New South Wales, Sydney, Australia

Full list of author information is available at the end of the article
}

non-AIDS events (SNAEs) has become more prominent especially in resource-rich settings [6,8-13] and in patients with higher CD4 T cell counts $[7,14]$.

\section{Definition of serious non-AIDS events}

Non-AIDS events (NAEs) are clinical events that do not meet the definition of AIDS-defining events based on the 1993 US Centers for Disease Control and Prevention (CDC) AIDS indicator conditions [15]. They encompass multiple diseases involving different organ systems, including cardiovascular, liver and renal disease, nonAIDS-defining malignancies, diabetes, neuropsychiatric disorders and bone-related abnormalities [16].

SNAEs are NAEs that result in death, are life-threatening, cause prolonged hospitalization and persistent incapacity or are associated with significant morbidity $[12,14,17]$. Most studies include cardiovascular, liver and end stage renal disease, as well as non-AIDS-defining cancers $[11,14,18,19]$. Other studies include an even broader range of conditions such as non-AIDS-related infections and psychiatric events

$[7,12,16,17,20]$.
C Biomed Central

(c) 2013 Hsu et al.; licensee BioMed Central Ltd. This is an Open Access article distributed under the terms of the Creative Commons Attribution License (http://creativecommons.org/licenses/by/2.0), which permits unrestricted use, distribution, and reproduction in any medium, provided the original work is properly cited. The Creative Commons Public Domain Dedication waiver (http://creativecommons.org/publicdomain/zero/1.0/) applies to the data made available in this article, unless otherwise stated. 


\section{Incidence of SNAEs}

The incidence of SNAEs in ART-treated patients is around 1 to 2 per 100 person-years of follow-up (PYFU) [11,14,17-19,21], (Table 1), but can be up to 60 per 100 PYFU in a cohort of treatment-experienced patients with multidrug resistant virus [12]. The relative contribution of non-AIDS malignancy, cardiovascular, liver and end stage renal disease to SNAEs vary across studies due to inconsistencies in the definition of SNAEs and differences in the rates of underlying co-morbidities e.g. Hepatitis $B$ virus $(\mathrm{HBV})$ and Hepatitis $\mathrm{C}$ virus $(\mathrm{HCV})$ co-infection. However, non-AIDS malignancy, cardiovascular disease (CVD) and liver disease combined seem to account for $>80 \%$ of SNAEs according to several published studies $[9,11,14,17,18]$. The incidence of non-AIDS malignancy and cardiovascular disease is about 2-fold higher in HIVinfected patients in the ART era when compared to the general population [22-26].

SNAEs are associated with worse outcome than AIDS events in the ART era. Compared with ART-treated patients without events, the risk of death is increased by 7 to 11 -fold in those with SNAEs and by 4 to 5 -fold in those with AIDS events [11,14]. Amongst SNAEs, liverrelated events are associated with the highest mortality $[11,14]$, followed by renal events, malignancies and cardiovascular events, with estimated 12-month mortality of $39.7,32.7,29.5$ and $6.1 \%$ respectively [11].

\section{SNAEs pathogenesis}

Prior to the Strategies for Management of Antiretroviral Therapy (SMART) Study, ART toxicities were thought to be a major contributor to SNAEs. In the SMART Study, over 5000 HIV-infected patients with CD4 T cell count $>350$ cells $/ \mu \mathrm{L}$ were randomized to either episodic ART (when CD4 T cell count fell below 250 cells/ $\mu \mathrm{L}$ ) or continuous ART. Patients on episodic ART had 1.8-fold increase in mortality and 1.7-fold increase in SNAEs (defined as major cardiovascular, renal or hepatic disease) when compared to those on continuous ART [27], thereby highlighting the role of HIV viraemia and immunodeficiency in the pathogenesis of SNAEs [28].

The pathogenesis of SNAEs is in fact multifactorial and complex (Figure 1). The direct effect of HIV and associated immunodeficiency, underlying co-morbidities and co-infections, immune activation with associated inflammation and coagulopathy as well as ART toxicities can all contribute.

\section{The direct effect of HIV}

Uncontrolled HIV replication causes immune activation and progressive decline in CD4 $\mathrm{T}$ cell count [29]. In addition, HIV can also contribute directly to organ dysfunction and SNAEs. HIV can infect human hepatic stellate cells and induce collagen expression and pro- inflammatory cytokines secretion in vitro [30,31]. HIV can also mediate dysregulation of glomerular podocytes in HIV-transgenic mouse models [32], as well as apoptosis of human renal tubular cell lines [33]. Therefore, direct effect of HIV may contribute to decline in renal function and increase risk of chronic kidney disease [34]. HIV may contribute directly to non-AIDS malignancy [35], as it can be oncogenic by activating proto-oncogenes [36] or by blocking tumour suppressor genes [37] in cell lines. Increased rates of microsatellite instability in tumours of $\mathrm{HIV}$-infected patients have also been found [38].

\section{Immunodeficiency}

Lower nadir or pre-ART CD4 T cell count is associated with increased risk of SNAEs [11,14,16,39]. In addition, the degree of CD4 $\mathrm{T}$ cell recovery after ART initiation also influences the incidence of SNAEs [14,18,21,39]. A 100 cells $/ \mu \mathrm{L}$ lower latest CD4 T cell count in ARTtreated patients is associated with a $30 \%$ increase in the risk of SNAEs, even after adjusting for smoking status, diabetes mellitus, hyperlipidaemia, $\mathrm{HCV}$ and $\mathrm{HBV}$ coinfection and alcohol abuse [18]. Lower latest CD4 T cell count in ART-treated patients is also associated with an increase in mortality $[40,41]$.

Suboptimal restoration of CD4 T cells may be secondary to a number of factors including decreased thymic function $[42,43]$ and impaired homeostatic responses and survival of $\mathrm{T}$ cells [44]. HIV replication and immune activation stimulate the secretion of transforming growth factor (TGF- $\beta$ ), mainly by regulatory $\mathrm{T}$ cells, with macrophages also contributing. TGF- $\beta$ triggers collagen production by fibroblasts [45-47]. The resultant structural damage and fibrosis of the lymphoid tissues restricts $\mathrm{T}$ cell access to interleukin-7 (IL-7) on the fibroblastic reticular cell (FRC) network [45] thus limiting naïve CD4 T cell survival $[48,49]$. Furthermore, ongoing immune activation leads to rapid CD4 $\mathrm{T}$ cell turnover, overwhelming the already impaired renewal mechanisms [44], resulting in suboptimal CD4 recovery [50,51].

\section{Co-infections}

Due to common routes of transmission, HIV-infected patients also have increased risk of exposure to other infections that can cause organ dysfunction.

About $6-14 \%$ of HIV-infected patients have HBV and about $25-30 \%$ have $\mathrm{HCV}$ infection, with the rates varying depending on endemicity of HBV in the population and the prevalence of injecting drug use [52]. HBV and/or $\mathrm{HCV}$ co-infection greatly increases the risk of SNAEs despite ART $[9,11,14,18,39,53]$. Co-infection with HCV is associated with increased risk of renal disease (1.5-fold) [54,55], cardiovascular disease (1.5-fold) [56], cirrhosis (19-fold) and hepatocellular carcinoma (5-fold) [57] 
Table 1 Summary of studies describing the incidence of SNAEs in various patient populations

\begin{tabular}{|c|c|c|c|c|c|c|c|c|c|c|c|}
\hline Study & Study population & $\mathbf{N}$ & $\begin{array}{l}\text { Median } \\
\text { follow-up } \\
\text { (yrs) }\end{array}$ & Male (\%) & $\begin{array}{l}\text { Median } \\
\text { age (yrs) }\end{array}$ & $\begin{array}{l}\text { Median nadir } \\
\text { CD4 count } \\
\text { (cells } / \mu \mathrm{L} \text { ) }\end{array}$ & $\begin{array}{l}\text { Median baseline } \\
\text { CD4 count } \\
\text { (cells } / \mu \mathrm{L} \text { ) }\end{array}$ & $\begin{array}{l}\text { HBV } \\
+(\%)\end{array}$ & $\begin{array}{l}\mathrm{HCV} \\
+(\%)\end{array}$ & $\begin{array}{l}\text { Rate of SNAEs } \\
\text { per } 100 \text { PYFU }\end{array}$ & Ref \\
\hline EuroSIDA & $\begin{array}{l}\text { A prospective observational cohort of HIV-infected } \\
\text { patients in Europe, Israel and Argentina followed } \\
\text { from 2001-09. }\end{array}$ & 12844 & & 73 & 39 & 178 & 403 & 6 & 24 & 1.8 & [14] \\
\hline \multirow[t]{2}{*}{$\begin{array}{l}\text { SMART (S) } \\
\text { ESPRIT(E) }\end{array}$} & $\begin{array}{l}\text { S: HIV-infected patients with CD } 4 \text { count }>350 \text { cells/ } \mu \mathrm{L} \\
\text { were randomized to either CD4 count guided episodic } \\
\text { use of ART or to continuous use of ART. E: HIV-infected } \\
\text { patients with CD4 count }>300 \text { cells/ } / \mu \mathrm{L} \text { were randomized } \\
\text { to interleukin-2 plus ART or to ART alone. }\end{array}$ & $\begin{array}{l}\text { S: } 5472 \\
\text { E: } 4111\end{array}$ & $\begin{array}{l}\text { S: } 2.4 \\
\text { E: } 6.8\end{array}$ & $\begin{array}{l}\text { S: } 73 \\
\text { E: } 81\end{array}$ & S: 43 E: 40 & S: 250 E: 197 & S: 597 E: 457 & $\mathrm{~s}: 2$ & S: 15 & 1 & {$[11,27,127]$} \\
\hline & $\begin{array}{l}\text { An observational cohort of HIV-infected patients with CD4 } \\
\text { count }>500 \text { cells/ } / \mathrm{L} \text { in Spain from 1996-2011. }\end{array}$ & 547 & 10 & 80 & 43 & 348 & 630 & 5 & 28 & 1.4 & [17] \\
\hline \multirow[t]{2}{*}{ CoRIS } & $\begin{array}{l}\text { A prospective multicenter observational cohort of } \\
\text { HIV-infected patients in Spain followed from 2004-2010. }\end{array}$ & 5185 & 2.1 & 79 & 36 & & 342 & 4 & 12 & 2.9 & [16] \\
\hline & $\begin{array}{l}\text { A retrospective study of HIV-infected patients receiving } \\
\text { ART in Botswana (B) and Nashville, USA (US); from } \\
2002 \text { (B) and } 2003 \text { (US)-2007. }\end{array}$ & $\begin{array}{l}\text { B: } 650 \\
\text { US: } 1129\end{array}$ & $\begin{array}{l}\text { B: } 3 \\
\text { US: } 1.5\end{array}$ & $\begin{array}{l}\text { B: } 31 \\
\text { US: } 74\end{array}$ & $\begin{array}{l}\text { B: } 33 \text { US: } \\
40\end{array}$ & & B: 199 US: 243 & & & B: 1 US: 1.2 & [19] \\
\hline LATINA & $\begin{array}{l}\text { A retrospective study of HIV-infected patients in } \\
\text { Latin America from 1997-2007. }\end{array}$ & 6007 & 2.5 & 70 & & & & & & 0.9 & [18] \\
\hline $\begin{array}{l}\text { APROCO/ } \\
\text { COPILOTE }\end{array}$ & $\begin{array}{l}\text { A prospective observational cohort of HIV-infected } \\
\text { patients in France followed from 1997-2006. }\end{array}$ & 1231 & 7.3 & 77 & 36 & & 279 & 5 & 23 & 10.5 & [20] \\
\hline OPTIMA & $\begin{array}{l}\text { HIV-infected patients with resistance to at least } 2 \\
\text { different multidrug regimens were randomized to } \\
\text { (a) re-treatment with either standard }(\leq 4) \text { or } \\
\text { intensive }(\geq 5) \text { antiretroviral drugs and (b) either } \\
\text { treatment starting immediately or after a 12-week } \\
\text { monitored ART interruption. }\end{array}$ & 368 & 4 & 98 & 48 & & 107 & 11 & 22 & 61.0 & {$[12]$} \\
\hline ATHENA & $\begin{array}{l}\text { An observational cohort of ART naive HIV-infected } \\
\text { patients starting ART in the Netherlands, 1996-2010. }\end{array}$ & 6440 & 3.9 & 75 & 39 & & 200 & 7 & 6 & 1.2 & [21] \\
\hline
\end{tabular}




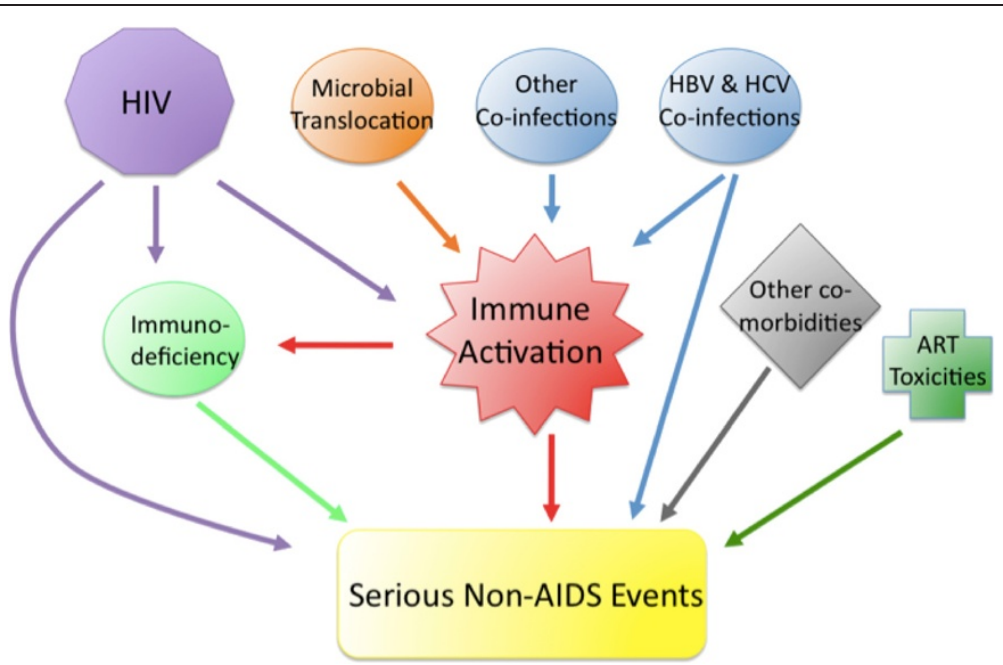

Figure 1 Pathogenesis of serious non-AIDS events. HIV infection causes progressive decline in CD4 T cells through direct cytopathic effects and immune mediated killing of infected cells, as well as indirectly via immune activation. Other drivers of immune activation include co-infections and microbial translocation. HIV can contribute to organ dysfunction through detrimental effects on hepatic stellate cells and renal tubular cells. HIV may also be oncogenic. Co-infection with HBV and HCV is especially important in liver related events. In addition, patients' underlying co-morbidities e.g. smoking, cardiovascular risk factors, and ART related toxicities also contribute to SNAES.

when compared with HIV mono-infected patients in the ART era.

HIV-infected patients also have increased risk of exposure to Human papillomavirus (HPV) [58], that is implicated in the pathogenesis of cervical and anal cancer $[59,60]$.

\section{Other co-morbidities}

HIV-infected patients also have higher prevalence of traditional cardiovascular risk factors such as smoking [61-63], elevated total cholesterol/HDL ratio [61-64] and substance abuse [65]. Some studies also found higher rates of hypertension and diabetes [64,66], but these findings have not been confirmed by others $[62,63,67]$.

Smoking is a major cause of increased mortality in ART-treated patients, accounting for a loss of $>12$ life years, and is associated with $>4$-fold increase in all-cause mortality, $>5$-fold increase in non-AIDS mortality, $>4$ fold increase in cardiovascular-related mortality and $>3$ fold increase in cancer-related mortality [68].

Though uncontrolled HIV replication, immunodeficiency, co-infection and co-morbid conditions are important contributors to the pathogenesis of SNAEs, these factors only partially account for the increased risk of SNAEs in HIV-infected patients. HIV elite controllers have increased coronary plaques and carotid intima media thickness when compared to uninfected controls even after adjustment for traditional cardiovascular risk factors $[69,70]$, demonstrating that factors other than uncontrolled viral replication, immunodeficiency, traditional risk factors, and ART toxicities contribute to increased cardiovascular risks in HIV-infected patients.

\section{Immune activation}

Inflammation is central to the process of atherosclerosis $[71,72]$, tumour progression [73,74] and liver fibrosis $[75,76]$ in the general population. High levels of biomarkers associated with inflammation (C-reactive protein, CRP, and IL-6) and coagulopathy (D-dimer and fibrinogen) are associated with increased risk of cardiovascular disease [77-80], increased cancer risks [81-83] and mortality $[80,84-86]$ in the general population.

In HIV-infected patients, CRP, IL-6 and D-dimer levels [61] as well as markers of $\mathrm{T}$ cell activation $[50,87]$ remain higher than uninfected controls despite suppressive ART. Furthermore, higher CRP, IL-6 and D-dimer [88-90], soluble CD14 (sCD14, a marker of LPS-induced monocyte activation) [91] and lymphocyte activation markers [92] are associated with higher mortality.

In ART-treated patients, CRP, IL-6 and D-dimer levels are also associated with increased risk of CVD, independent of other CVD risk factors [93,94]. These markers are also associated with increased risks of both infection-related and infection unrelated cancers even after adjusting for demographics and CD4 $\mathrm{T}$ cell count [95]. Recently, higher levels of tumour necrosis factor (TNF) were also found to be significantly associated with increased risk of SNAEs [96]. Therefore these data suggest that immune activation plays a very important role in SNAEs pathogenesis.

\section{Intermittent viraemia}

The drivers of immune activation are diverse. Intermittent HIV viraemia can occur in $20-30 \%$ of ART-treated patients $[97,98]$. The presence of viraemia whilst on 
ART is associated with higher IL-6, D-dimer and sCD14 levels [62] and SNAEs [11,39]. In addition, viraemia below the limit of detection of conventional assays also correlates with persistent $\mathrm{T}$ cell activation [99]. Therefore, residual viraemia may partially be responsible for persistent immune activation despite ART.

\section{Co-infections}

The presence of co-infections also contributes to continual stimulation and activation of the immune system. Asymptomatic CMV infection has been associated with CD8 T cell activation in ART-treated patients [100]. CMV specific CD4 $\mathrm{T}$ cells can cause a systemic inflammatory response that is sustained even during latent infection [101] and is associated with atherogenesis $[102,103]$. Hepatitis C co-infection is also associated with increased CD8 $\mathrm{T}$ cell activation when compared with HIV mono-infected patients despite ART $[104,105]$.

\section{Microbial translocation}

Microbial translocation due to impaired mucosal barrier integrity may be another cause of immune activation in HIV infection. Rhesus macaques with chronic SIV infection have disruptions of the epithelial barrier of the colon and increased lipopolysaccharide (LPS) staining. The levels of LPS staining in the colon also correlated with the levels of LPS in the draining lymph nodes and remote peripheral lymph nodes [106]. African green monkeys are natural hosts of SIV. In chronic SIV infection, they display little immune activation, maintain mucosal barrier integrity and do not progress to AIDS [107]. However, the injection of LPS into SIV-infected African green monkeys was associated with increases in T cell activation, sCD14 and SIV viraemia [108]. In HIVinfected patients, plasma LPS also correlated with plasma interferon (IFN)- $\alpha$ and $\mathrm{T}$ cell activation levels [109]. These data suggest that impaired mucosal barrier integrity and microbial translocation may induce immune activation.

Markers of microbial translocation e.g. LPS, sCD14 [110] and bacterial $16 \mathrm{~s}$ rDNA [111] do not always normalise with ART. LPS can induce tissue factor expression on monocytes [112]. Tissue factor is the initiator of the coagulation cascade [113] and its expression on monocytes is correlated with D-dimer levels [112]; suggesting that microbial translocation may contribute to atherogenesis and increased CVD [112].

\section{Antiretroviral therapy}

Finally, adverse effects of ART may also contribute to SNAEs. A detail review of ART-related toxicities is beyond the scope of this review. Protease inhibitors as a class, as well as indinavir, lopinavir and abacavir may be associated with increased risk of CVD [25,114,115].
Some studies found that the rate of liver-related deaths is increased per year of ART [116,117]. The cohort described by Weber et al have high rates of HBV and HCV infection, $17 \%$ and $66 \%$, respectively [116]. Though patients with HBV or HCV infection have about 5fold greater risk of hepatotoxicity after ART initiation [118-120], ART is essential as it slows fibrosis progression [121] and reduces liver-related mortality by about 10-fold [122]. In patients without chronic viral hepatitis, ART toxicity rarely causes liver-related mortality, at a rate of 0.04 per 1000 person years [123].

ART has been associated with improved renal function and a slower rate of eGFR decline in HIV-infected patients $[124,125]$. Though tenofovir use is associated with higher risk of acute renal injury and greater loss of renal function than other ART regimen, the overall risk of serious renal event is not high, in $0.5 \%$ of patients [126].

\section{Interventions to reduce SNAEs}

Strategies to reduce SNAEs include preventing and reversing immunodeficiency, the modification of traditional risk factors, treatment of co-infections and addressing drivers of immune activation. A wide variety of agents are currently being examined for their potential effects in reducing immune activation and SNAEs (Table 2). However, the majority of studies that have been performed are small, are heterogeneous in terms of ART status and show conflicting findings. The majority of studies used markers of immune activation, in particular CD8 $\mathrm{T}$ cell activation as outcome measures. Some recent studies have also included sCD14 and D-dimer. However, randomized placebo-controlled trials that use clinical outcome measures are rare [127].

\section{Preventing and reversing immunodeficiency ART initiation prior to advanced immunodeficiency}

Data from randomized controlled trials suggest that deferral of ART initiation until CD4 T cell count $<250$ cells $/ \mu \mathrm{L}$ was associated with increased SNAEs, AIDS-related events and mortality [128-130]. Observational studies suggest that ART initiation at CD4 T cell count $>350$ cells $/ \mu \mathrm{L}$ is associated with lower risk of SNAEs [14], AIDSdefining illness or death when compared to deferring ART [131-134]. The benefit of ART initiation at CD4 T cell count $>350$ cells $/ \mu \mathrm{L}$ when compared to deferring until CD4 T cell count $\sim 350$ cells $/ \mu \mathrm{L}$ is insignificant in some studies when the analysis is restricted to mortality alone $[131,134]$. Results from the START study (NCT00867048), a multicenter international trial designed to assess the risks and benefits of initiating ART at CD4 T cell count at $>500$ or $<350$ cells/ $\mu \mathrm{L}$ will likely shed further light on this issue. Nonetheless, given that the majority of HIVinfected patients start ART with CD4 T cell count $<250$ cells $/ \mu \mathrm{L}[135,136]$, earlier HIV diagnosis and initiation 
Table 2 Potential strategies to reduce SNAEs

\begin{tabular}{|c|c|c|}
\hline Potential strategies to reduce SNAEs & Interventions investigated or under evaluation & References \\
\hline Preventing immunodeficiency & Initiate ART prior to advanced immunodeficiency & {$[14,128-134]$} \\
\hline \multicolumn{3}{|l|}{ Increasing CD4 T cell recovery } \\
\hline \multirow[t]{2}{*}{ Cytokine therapy } & Subcutaneous IL-2 & {$[127]$} \\
\hline & Subcutaneous IL-7 & {$[137,138]$} \\
\hline \multirow[t]{3}{*}{ Modulating lymphoid tissue fibrosis } & Pirfenidone & Human data pending \\
\hline & Angiotensin receptor antagonist & Human data pending \\
\hline & ACE inhibitor & Human data pending \\
\hline \multirow[t]{3}{*}{ Managing co-morbidities } & Smoking cessation & {$[68,145]$} \\
\hline & Optimise blood pressure, lipids and diabetic control & {$[146,147]$} \\
\hline & ART switch & [152-160] \\
\hline \multicolumn{3}{|l|}{ Reducing chronic antigen stimulation } \\
\hline \multirow[t]{2}{*}{ Residual viraemia } & Raltegravir intensification & {$[161-170]$} \\
\hline & Maraviroc intensification & {$[171-174]$} \\
\hline HBV and HCV co-infection & Hepatitis B and C treatment & {$[105,175,176]$} \\
\hline CMV co-infection & Valganciclovir & [178] \\
\hline HSV co-infection & Valacyclovir & {$[179]$} \\
\hline \multirow[t]{6}{*}{ Reducing inflammation } & Statins & {$[182-187]$} \\
\hline & COX-2 inhibitors & {$[195,196]$} \\
\hline & Aspirin & [199] \\
\hline & Hydroxychloroquine \& Chloroquine & [191-193] \\
\hline & Leflunomide & {$[200]$} \\
\hline & Prednisone & {$[201-204]$} \\
\hline \multicolumn{3}{|l|}{ Reducing microbial translocation } \\
\hline Balancing microbiota & Prebiotic, probiotic and synbiotic & {$[210-213]$} \\
\hline \multirow[t]{3}{*}{ Reducing bacterial/endotoxin load } & Rifaximin & Human data pending \\
\hline & Bovine colostrum & {$[167]$} \\
\hline & Sevelamer & Human data pending \\
\hline Improving mucosal integrity & Lubiprostone & Human data pending \\
\hline Reducing inflammation in the gut & Mesalamine & Human data pending \\
\hline
\end{tabular}

of ART before advanced immunodeficiency will likely reduce SNAEs.

\section{Improving CD4 T cell recovery}

A number of studies have investigated the use of cytokines critical for $\mathrm{T}$ cell homeostasis e.g. IL-2 and IL-7 to enhance CD4 T cell recovery. Though subcutaneous IL-2 administration in concert with ART resulted in sustained increase in CD4 $\mathrm{T}$ cell count, this did not translate into clinical benefit [127]. Subcutaneous IL-7 administration also leads to increase in CD4 T cells in phase I and II studies $[137,138]$ but clinical outcomes have not yet been assessed. The restoration of TH17 cells and improvement in TH17/T regulatory cell ratio may be especially important given their roles in mucosal immunity $[139,140]$.

\section{Modulating the effects of lymphoid tissue fibrosis}

Lymphoid tissue fibrosis is associated with poor CD4 $\mathrm{T}$ cell restoration after ART initiation [49]. TGF- $\beta$ is key in the process of lymphoid tissue fibrosis. Pirfenidone can reduce TGF- $\beta$ production and has antifibrotic effects $[45,141]$. Pirfenidone administered to rhesus macaques prior to SIV infection was associated with reduced lymph node fibrosis and preservation of lymph node CD4 T cells [142]. TNF blockade with adalimumab was also associated with attenuated TGF$\beta$ expression, reduced lymph node fibrosis and preserved lymph node architecture in a recent rhesus macaque study [47]. The effect of pirfenidione or adalimumab on lymph node fibrosis in HIV infection has not been studied to date. 
The renin-angiotensin pathway is involved in cardiac, renal and liver fibrosis. Binding of angiotensin II to the angiotensin 1 receptor on cardiac fibroblast, hepatic stellate cells or mesangial cells leads to proliferation as well as collagen and TGF- $\beta$ synthesis $[143,144]$. Trials on the effect of angiotensin converting enzyme (ACE) inhibitor e.g. lisinopril (ClinicalTrials.gov identifier: NCT01535235), angiotensin II receptor antagonists e.g. losartan (NCT01852942, NCT01529749) and telmisartan (NCT01928927) in modulating lymphoid tissue fibrosis are currently underway.

\section{Optimizing cardiovascular risk factors}

In the D.A.D study, patients who stopped smoking had about 30\% reduction in the risk of CVD [145]. Surprisingly, a reduction in mortality was not seen. This may be because patients ceased smoking after the diagnosis of a serious illness and succumb before the benefit of smoking cessation on mortality can be seen [145]. In the Danish HIV cohort, previous smokers had a $>1.5$-fold reduction in mortality when compared with current smokers. In addition, though previous smokers have higher rates of AIDS-related deaths when compared with never smokers, the incidence of non-AIDS-related death was not different between previous and never smokers [68]. These data suggest that smoking cessation alone would result in significant benefits and should be encouraged.

Modification of other cardiovascular risk factors e.g. treatment of hypertension, dyslipidaemia and optimal glycaemic control in diabetic patients is critical. Suggested target levels have been published [146,147]. Each $10 \mathrm{mmHg}$ reduction in systolic blood pressure and each $38 \mathrm{mg} / \mathrm{dL}$ reduction in total cholesterol is associated with a 5 and $20 \%$ reduction in risk of CVD, respectively [148]. However, in patients with known hypertension, diabetes or dyslipidaemia meeting indication for treatment, over $40 \%$ were not on treatment [149]. Given that a significant proportion of SNAEs are cardiovascular events, more aggressive detection and management of cardiovascular risk factors will likely reduce SNAEs.

ART modification is a potential strategy to reduce cardiovascular risk [150]. A recent review of switch studies have been published [151]. Switching from stavudine to tenofovir was associated with a reduction in total cholesterol and triglycerides and an increase in limb fat [152]. Switching from protease inhibitors to efavirenz or nevirapine was associated with reduction in total cholesterol [153]. However, this switch is not possible in patients with non-nucleoside reverse transcriptase inhibitor resistance. Switching from lopinavir/ritonavir to atazanavir (both boosted with ritonavir $100 \mathrm{mg}$ or unboosted) was associated with reduction of total cholesterol and triglycerides, though greater reductions were seen with unboosted atazanavir [154-156]. Switching to atazanavir was also associated with a reduction in cardiovascular risk score [157]. Though switching from lopinavir/ritonavir to raltegravir was associated with improvement in lipid profile $[158,159]$, no change in endothelial function was detected [160]. The importance of having fully active backbone antiretrovirals was highlighted in the SWITCHMRK study where patients switched to raltegravir had higher rates of virologic failure [158].

\section{Suppressing chronic antigen stimulation Reducing residual viraemia}

Intensification studies have been performed to assess the impact of adding antiretroviral agents to a suppressive ART regimen (as measured by conventional assays). None of the raltegravir intensification studies were able to demonstrate reduction in ultra-sensitive plasma HIVRNA levels [161-167]. In addition, the majority of studies also found no reduction in markers of $\mathrm{T}$ cell [161-164,167] or monocyte activation [167]. However, some studies have noted a reduction in D-dimer levels [168], T cell activation [165,166,169] as well as an early transient increase in 2-LTR circles post raltegravir intensification $[168,170]$, suggesting that residual viraemia was occurring prior to raltegravir intensification and was contributing to immune activation in some patients.

Maraviroc intensification studies have also been performed and yielded conflicting data. Some found reduction in $\mathrm{T}$ cell activation [171-173] whilst others found increase in CD4 and CD8 T cell activation both in the peripheral blood and in the rectal mucosa after maraviroc intensification [174]. Hunt et al postulated that the binding of maraviroc to CCR5 prevents the interaction between CCR5 and its natural ligands. Excess CCR5 ligands may then bind to other chemokine receptor such as CCR3 and CCR4 on T cells, leading to T cell activation [174]. Therefore, the beneficial effect of adding antiretroviral agents to an already suppressive ART regimen is uncertain based on currently available data.

\section{Treating other co-infections}

$\mathrm{HCV}$ treatment and suppression of $\mathrm{HCV}$ viraemia is associated with reductions in CD4 and CD8 T cell activation [105]. Sustained virologic response is associated with reduced liver-related complications as well as both liver-related and non liver-related mortality in co-infected patients $[175,176]$. Unfortunately, HCV treatment may be limited by contraindications, adverse events, high costs, and drug interactions. Next generation agents with higher efficacy and better side effect profiles may revolutionise the management of $\mathrm{HIV} / \mathrm{HCV}$ co-infected patients [177].

Treatment of other persistent viral infection has also been investigated. Eight weeks of valganciclovir in ARTtreated, CMV seropositive patients led to a significant reduction of $\mathrm{CMV}$ viraemia as well as a reduction in $\mathrm{CD} 8$ 
$\mathrm{T}$ cell activation [178]. In a study targeting HSV coinfection using 12 weeks of valacyclovir in ART-treated, HSV-1 and HSV-2 seropositive patients, no change in T cell activation, CRP or IL-6 levels was demonstrated [179].

\section{Anti-inflammatory agents}

Statins are 3-hydroxy-3-methyl-glutaryl-coenzyme A reductase inhibitors. Not only do statins reduce serum cholesterol [180], they may also have anti-inflammatory properties [181]. Statin use is associated with reduced monocyte activation (unpublished data McComsey et al), decline in CRP levels [182] as well as reduced T cell activation [183] in ART-treated and in untreated, HIVinfected patients [184]. A retrospective observational study of ART-treated patients showed that statin use is associated with a 3-fold reduction in mortality [185]. Though not statistically significant, a trend for reduction in SNAEs [186] and mortality [187] has also been seen in other retrospective observational studies.

Hydroxychloroquine (HCQ) and its analogue chloroquine $(\mathrm{CQ})$ have immunomodulatory, anti-inflammatory and anti-HIV properties [188-190]. In patients with uncontrolled viral replication, the use of CQ was associated with reduced CD8 T cell activation [191] whereas the same effect was not seen with HCQ [192]. However a non-randomized study of HCQ in 20 ART-treated patients showed decline in plasma LPS, IL-6 and reduced $\mathrm{T}$ cell and monocyte activation [193]. Thus findings are inconclusive.

COX-2 inhibitors inhibit cyclooxygenase type 2, reducing Prostaglandin E2 production, thereby reducing activation of $\mathrm{T}$ cells through the cyclic adenosine monophosphate (cAMP) pathway [194]. Studies on COX-2 inhibitors have been small and reduction in $\mathrm{T}$ cell activation tended to occur in viraemic patients $[195,196]$. However, it is important to bear in mind that COX-2 inhibitors are associated with increased cardiovascular risk, via a direct pharmacologic consequence of inhibition of COX-2 [197]. Therefore assessing the utility of COX2 inhibitors without using clinical outcome measures may be insufficient.

Aspirin is a cornerstone in the secondary prevention of vascular disease [198]. In a pilot study, aspirin use was associated with reduced platelet activation, a decrease in sCD14 in monocytes and reductions in CD38 and HLA-DR on CD4 and CD8 T cells. However, there was no change in IL-6, D-dimer and CRP [199]. An aspirin study with larger number of participants is in development with the AIDS Clinical Trials Group.

Leflunomide is an immunomodulatory agent that is used in the treatment of rheumatoid arthritis. The administration of leflunomide in untreated, HIV-infected patients for 28 days was associated with a decrease in CD8 T cell activation [200].
The use of prednisone in patients with untreated chronic HIV infection was associated with less CD4 T cell depletion, a decline in CD4 $\mathrm{T}$ cell activation and stable HIV viral load [201,202]. Prednisone at $0.5 \mathrm{mg} / \mathrm{kg} /$ day in ART-treated patients was also associated with a reduction in CD8 T cell activation and TNF levels as well as a transient decrease in IL-6 [203]. However, in another study using prednisone at $40 \mathrm{mg} /$ day, no reduction in CD4 or CD8 T cell activation, plasma IL-6 or TNF levels was found [204]. Furthermore, long-term prednisone use, especially at doses $>7.5 \mathrm{mg} /$ day is associated with significant adverse effects such as osteoporosis, impaired glucose tolerance, dyslipidaemia, weight gain, cataract formation and increased risk of infections [205]. Even short courses have been associated with an increased risk of osteonecrosis in HIV-infected patients [206].

\section{Targeting microbial translocation}

Given that HIV infection has been associated with depressed levels of beneficial gut microbiota and elevated levels of pathogenic microbiota [207], a range of prebiotics (selectively fermented ingredients that changes the growth and/or activity of certain gut microflora, resulting in health benefits [208]), probiotics (live microorganisms that when consumed, confer a health benefit [209]) and synbiotics (combinations of pre and probiotics) are under investigation.

A prebiotic oligosaccharide mixture has been associated with improvement in microbiota composition and reduction in SCD14 in untreated HIV-infected patients [210]. A retrospective cohort study on both ART-treated and untreated HIV-infected patients found that probiotic yogurt consumption was associated with a greater increase in CD4 $\mathrm{T}$ cell count even after adjustment for ART [211]. A double-blind randomized placebo-controlled trial in 20 untreated HIV-infected patients found reductions in plasma bacterial DNA and IL-6 levels in patients receiving synbiotics [212]. However, a synbiotic agent in ART-treated women found no change in microbial translocation nor immune activation status despite improvement in the levels of probiotic species [213]. Therefore, more randomized controlled clinical trial data are needed to clarify the effects of pre and probiotics in reducing immune activation.

Bovine colostrum contains oligosaccharides, growth factors, immunoglobulins and antimicrobial peptides and has some activity in alleviating HIV-associated diarrhoea in single arm studies [214-216]. However a randomized controlled trial on the addition of bovine colostrum to suppressive ART found no change in CD4 $\mathrm{T}$ cell count, markers of microbial translocation nor $\mathrm{T}$ cell activation [167].

A number of new agents that target microbial translocation are under evaluation. Rifaximin is a minimally 
absorbed oral rifamycin antibiotic that has activity against both gram-positive and gram-negative enteric bacteria [217]. It is effective in the treatment of hepatic encephalopathy, by reducing ammonia-producing enteric bacteria $[218,219]$. There are currently 3 clinical trials of rifaximin in HIV-infected patients (ClinicalTrials.gov identifier: NCT01654939, NCT01866826 and NCT01466595). Lubiprostone is a chloride channel activator that is used in the treatment of constipation [220]. It has been found to enhance recovery of mucosal barrier function in ischaemic porcine colon [221]. A pilot study of lubiprostone in ART treated, virologically suppressed patients with CD4 T cell count $<350$ cells $/ \mu \mathrm{L}$ (NCT01839734) is currently recruiting. Sevelamer is a phosphate binder that is used in patients with end-stage renal failure [222]. It can also bind to endotoxins and reduce CRP, IL- 6 and SCD14 in patients on haemodialysis $[223,224]$. The trial in untreated, HIVinfected patients (NCT01543958) was completed in June 2013 and results are pending. Mesalamine (5-aminosalicylic acid) is an anti-inflammatory agent used in the management of inflammatory bowel disease [225]. A trial using mesalamine in ART treated, virologically suppressed patients with CD4 T cell count $<350$ cells $/ \mu \mathrm{L}$ (NCT01090102) is currently enrolling.

\section{Conclusions}

Despite the use of ART, HIV-infected patients still have higher mortality and morbidity when compared to the general population. SNAEs occur at the rate of about 1-2 per 100 PYFU and are the predominant causes of morbidity and mortality in HIV-infected patients in the ART era. Many factors contribute to the pathogenesis of SNAEs including the direct effect of HIV and associated immunodeficiency, underlying co-morbidities, immune activation and ART toxicities. Though multiple interventions have been investigated or are ongoing, most of the studies are small, of short duration and clinical outcome measures have not been ascertained. The cost required to investigate the effectiveness of an intervention to reduce SNAEs may be prohibitively high as it will require thousands of participants with possibly several years of follow up.

Currently, the interventions with evidence to suggest an association with reduced risk of SNAEs or mortality are starting ART before advanced immunodeficiency, smoking cessation, optimisation of cardiovascular risk factors and treatment of $\mathrm{HCV}$ infection. Clinicians should focus their attention on addressing these issues prior to the availability of further data.

\section{Abbreviations}

ACE: Angiotensin converting enzyme; ART: Antiretroviral therapy: CAMP: Cyclic adenosine monophosphate; CDC: Centers for disease control and prevention; CQ: Chloroquine; CRP: C-reactive protein; CVD: Cardiovascular disease; EBV: Epstein-Barr virus; FRC: Fibroblastic reticular cell; HBV: Hepatitis B virus; HCV: Hepatitis C virus; HCQ: Hydroxychloroquine; HPV: Human papillomavirus; IL-7: Interleukin-7; IFN: Interferon; LPS: Lipopolysaccharide; NAEs: Non-AIDS events; PYFU: Person-years of follow-up; SCD14: Soluble CD14; SIR: Standardized incidence ratio; SMART: Strategies for management of antiretroviral therapy; SNAEs: Serious non-AIDS events; START: Strategic timing of antiretroviral treatment; TGF: Transforming growth factor; TNF: Tumour necrosis factor.

\section{Competing interests}

The authors declare that they have no competing interests.

\section{Authors' contributions}

$\mathrm{DH}, \mathrm{JA}$, IS contributed to the writing of the manuscript. All authors read and approved the final manuscript.

\section{Author details}

${ }^{1}$ The Kirby Institute for Infection and Immunity in Society, University of New South Wales, Sydney, Australia. ${ }^{2}$ HIV Pathogenesis Unit, Laboratory of Immunoregulation, NIAID/NIH, Bethesda, MD, USA. ${ }^{3} \mathrm{HIV}$ Netherlands Australia Thailand Research Collaboration and SEARCH, Thai Red Cross AIDS Research Centre, Bangkok, Thailand.

Received: 1 October 2013 Accepted: 26 November 2013

Published: 13 December 2013

\section{References}

1. Harrison KM, Song R, Zhang X: Life expectancy after HIV diagnosis based on national HIV surveillance data from 25 states, United States. J Acquir Immune Defic Syndr 2010, 53:124-130.

2. Nakagawa F, Lodwick RK, Smith CJ, Smith R, Cambiano V, Lundgren JD, Delpech V, Phillips AN: Projected life expectancy of people with HIV according to timing of diagnosis. AIDS 2012, 26:335-343.

3. Lohse N, Hansen AB, Pedersen G, Kronborg G, Gerstoft J, Sorensen HT, Vaeth $M$, Obel N: Survival of persons with and without HIV infection in Denmark, 1995-2005. Ann Intern Med 2007, 146:87-95.

4. Life expectancy of individuals on combination antiretroviral therapy in high-income countries: a collaborative analysis of 14 cohort studies. Lancet 2008, 372:293-299.

5. Krentz HB, Kliewer G, Gill MJ: Changing mortality rates and causes of death for HIV-infected individuals living in Southern Alberta, Canada from 1984 to 2003. HIV Med 2005, 6:99-106.

6. Palella FJ Jr, Baker RK, Moorman AC, Chmiel JS, Wood KC, Brooks JT, Holmberg SD: Mortality in the highly active antiretroviral therapy era: changing causes of death and disease in the HIV outpatient study. $J$ Acquir Immune Defic Syndr 2006, 43:27-34.

7. Lau B, Gange SJ, Moore RD: Risk of non-AIDS-related mortality may exceed risk of AIDS-related mortality among individuals enrolling into care with CD4+ counts greater than 200 cells/mm3. J Acquir Immune Defic Syndr 2007, 44:179-187.

8. Reisler RB, Han C, Burman WJ, Tedaldi EM, Neaton JD: Grade 4 events are as important as AIDS events in the era of HAART. J Acquir Immune Defic Syndr 2003, 34:379-386.

9. Causes of death in HIV-1-infected patients treated with antiretroviral therapy, 1996-2006: collaborative analysis of 13 HIV cohort studies. Clin Infect Dis 2010, 50:1387-1396.

10. Lewden C, May T, Rosenthal E, Burty C, Bonnet F, Costagliola D, Jougla E, Semaille C, Morlat P, Salmon D, et al: Changes in causes of death among adults infected by HIV between 2000 and 2005: the "Mortalite 2000 and 2005" surveys (ANRS EN19 and Mortavic). J Acquir Immune Defic Syndr 2005, 2008(48):590-598.

11. Neuhaus J, Angus B, Kowalska JD, La Rosa A, Sampson J, Wentworth D, Mocroft A: Risk of all-cause mortality associated with nonfatal AIDS and serious non-AIDS events among adults infected with HIV. AIDS 2010, 24:697-706.

12. Anis AH, Nosyk B, Sun H, Guh DP, Bansback N, Li X, Barnett PG, Joyce V, Swanson KM, Kyriakides TC, et al: Quality of life of patients with advanced HIV/AIDS: measuring the impact of both AIDS-defining events and non-AIDS serious adverse events. J Acquir Immune Defic Syndr 2009, 51:631-639.

13. Kowalska JD, Reekie J, Mocroft A, Reiss P, Ledergerber B, Gatell J, d'Arminio Monforte A, Phillips A, Lundgren JD, Kirk O: Long-term exposure to 
combination antiretroviral therapy and risk of death from specific causes: no evidence for any previously unidentified increased risk due to antiretroviral therapy. AIDS 2012, 26:315-323.

14. Mocroft A, Reiss P, Gasiorowski J, Ledergerber B, Kowalska J, Chiesi A, Gatell J, Rakhmanova A, Johnson M, Kirk O, Lundgren J: Serious fatal and nonfatal non-AIDS-defining illnesses in Europe. J Acquir Immune Defic Syndr 2010, 55:262-270.

15. CDC: 1993 revised classification system for HIV infection and expanded surveillance case definition for AIDS among adolescents and adults. MMWR Recomm Rep 1992, 41:1-19.

16. Masia M, Padilla S, Alvarez D, Lopez JC, Santos I, Soriano V, HernandezQuero J, Santos J, Tural C, del Amo J, Gutierrez F: Risk, predictors, and mortality associated with non-AIDS events in newly diagnosed HIV-infected patients: role of antiretroviral therapy. AIDS 2013, 27:181-189.

17. Lucero C, Torres B, Leon A, Calvo M, Leal L, Perez I, Plana M, Arnedo M, Mallolas J, Gatell JM, Garcia F: Rate and Predictors of Non-AIDS Events in a Cohort of HIV-Infected Patients with a CD4 T Cell Count Above 500 Cells/mm(3.). AlDS Res Hum Retroviruses 2013, 29:1161-1167.

18. Belloso WH, Orellana LC, Grinsztejn B, Madero JS, La Rosa A, Veloso VG, Sanchez J, Ismerio Moreira R, Crabtree-Ramirez B, Garcia Messina O, et al: Analysis of serious non-AIDS events among HIV-infected adults at Latin American sites. HIV Med 2010, 11:554-564.

19. Wester CW, Koethe JR, Shepherd BE, Stinnette SE, Rebeiro PF, Kipp AM, Hong H, Bussmann H, Gaolathe T, McGowan CC, et al: Non-AIDS-defining events among HIV-1-infected adults receiving combination antiretroviral therapy in resource-replete versus resource-limited urban setting. AIDS 2011, 25:1471-1479.

20. Ferry T, Raffi F, Collin-Filleul F, Dupon M, Dellamonica P, Waldner A, Strady C, Chene G, Leport C, Moing VL: Uncontrolled viral replication as a risk factor for non-AIDS severe clinical events in HIV-infected patients on long-term antiretroviral therapy: APROCO/COPILOTE (ANRS CO8) cohort study. J Acquir Immune Defic Syndr 2009, 51:407-415.

21. Zhang S, van Sighem A, Kesselring A, Gras L, Smit C, Prins JM, Kauffmann R, Richter C, de Wolf F, Reiss P: Episodes of HIV viremia and the risk of non-AIDS diseases in patients on suppressive antiretroviral therapy. J Acquir Immune Defic Syndr 2012, 60:265-272.

22. Powles T, Robinson D, Stebbing J, Shamash J, Nelson M, Gazzard B, Mandelia S, Moller $\mathrm{H}$, Bower M: Highly active antiretroviral therapy and the incidence of non-AIDS-defining cancers in people with HIV infection. J Clin Oncol 2009, 27:884-890.

23. Bedimo RJ, MCGinnis KA, Dunlap M, Rodriguez-Barradas MC, Justice AC: Incidence of non-AIDS-defining malignancies in HIV-infected versus noninfected patients in the HAART era: impact of immunosuppression. J Acquir Immune Defic Syndr 2009, 52:203-208.

24. Shiels MS, Cole SR, Kirk GD, Poole C: A meta-analysis of the incidence of non-AIDS cancers in HIV-infected individuals. J Acquir Immune Defic Syndr 2009, 52:611-622.

25. Islam FM, Wu J, Jansson J, Wilson DP: Relative risk of cardiovascular disease among people living with HIV: a systematic review and meta-analysis. HIV Med 2012, 13:453-468.

26. Martinez E, Milinkovic A, Buira E, de Lazzari E, Leon A, Larrousse M, Lonca M, Laguno M, Blanco JL, Mallolas J, et al: Incidence and causes of death in HIV-infected persons receiving highly active antiretroviral therapy compared with estimates for the general population of similar age and from the same geographical area. HIV Med 2007, 8:251-258.

27. El-Sadr WM, Lundgren J, Neaton JD, Gordin F, Abrams D, Arduino RC, Babiker A, Burman W, Clumeck N, Cohen CJ, et al: CD4+ count-guided interruption of antiretroviral treatment. N Engl J Med 2006, 355:2283-2296.

28. Strategies for Management of Antiretroviral Therapy Study Group, Lundgren JD, Babiker A, El-Sadr W, Emery S, Grund B, Neaton JD, Neuhaus J, Phillips AN: Inferior clinical outcome of the CD4+ cell count-guided antiretroviral treatment interruption strategy in the SMART study: role of CD4+ Cell counts and HIV RNA levels during follow-up. J Infect Dis 2008, 197:1145-1155.

29. Lawn SD, Butera ST, Folks TM: Contribution of immune activation to the pathogenesis and transmission of human immunodeficiency virus type 1 infection. Clin Microbiol Rev 2001, 14:753-777.

30. Tuyama AC, Hong F, Saiman Y, Wang C, Ozkok D, Mosoian A, Chen P, Chen BK, Klotman ME, Bansal MB: Human immunodeficiency virus (HIV)-1 infects human hepatic stellate cells and promotes collagen I and monocyte chemoattractant protein-1 expression: implications for the pathogenesis of HIV/hepatitis C virus-induced liver fibrosis. Hepatology 2010, 52:612-622

31. Hong F, Saiman Y, Si C, Mosoian A, Bansal MB: X4 Human immunodeficiency virus type $1 \mathrm{gp} 120$ promotes human hepatic stellate cell activation and collagen I expression through interactions with CXCR4. Plos One 2012, 7:e33659.

32. Zuo Y, Matsusaka T, Zhong J, Ma J, Ma LJ, Hanna Z, Jolicoeur P, Fogo $A B$, Ichikawa I: HIV-1 genes vpr and nef synergistically damage podocytes, leading to glomerulosclerosis. J Am Soc Nephrol 2006, 17:2832-2843.

33. Kapasi AA, Fan S, Singhal PC: p300 modulates HIV-1 gp120-induced apoptosis in human proximal tubular cells: associated with alteration of TGF-beta and Smad signaling. Nephron Exp Nephrol 2006, 102:e30-e38.

34. Wyatt CM, Meliambro K, Klotman PE: Recent progress in HIV-associated nephropathy. Annual review of medicine 2012, 63:147-159.

35. Deeken JF, Tjen ALA, Rudek MA, Okuliar C, Young M, Little RF, Dezube BJ: The rising challenge of non-AIDS-defining cancers in HIV-infected patients. Clin Infect Dis 2012, 55:1228-1235.

36. Wright $\mathrm{S}$, Lu X, Peterlin BM: Human immunodeficiency virus type 1 tat directs transcription through attenuation sites within the mouse c-myc gene. J Mol Biol 1994, 243:568-573.

37. Harrod R, Nacsa J, Van Lint C, Hansen J, Karpova T, McNally J, Franchini G: Human immunodeficiency virus type-1 Tat/co-activator acetyltransferase interactions inhibit p53Lys-320 acetylation and p53-responsive transcription. J Biol Chem 2003, 278:12310-12318.

38. Bedi GC, Westra WH, Farzadegan H, Pitha PM, Sidransky D: Microsatellite instability in primary neoplasms from HIV + patients. Nat Med 1995, 1:65-68.

39. Baker JV, Peng G, Rapkin J, Abrams DI, Silverberg MJ, MacArthur RD, Cavert WP, Henry WK, Neaton JD: CD4+ count and risk of non-AIDS diseases following initial treatment for HIV infection. AIDS 2008, 22:841-848.

40. Marin B, Thiebaut R, Bucher HC, Rondeau V, Costagliola D, Dorrucci M, Hamouda O, Prins M, Walker S, Porter K, et al: Non-AIDS-defining deaths and immunodeficiency in the era of combination antiretroviral therapy. AIDS 2009, 23:1743-1753

41. Smith C, Sabin CA, Lundgren JD, Thiebaut R, Weber R, Law M, Monforte A, Kirk O, Friis-Moller N, Phillips A, et al: Factors associated with specific causes of death amongst HIV-positive individuals in the D:A:D Study. AIDS 2010, 24:1537-1548.

42. Haynes BF, Markert ML, Sempowski GD, Patel DD, Hale LP: The role of the thymus in immune reconstitution in aging, bone marrow transplantation, and HIV-1 infection. Annu Rev Immunol 2000, 18:529-560.

43. Douek DC, McFarland RD, Keiser PH, Gage EA, Massey JM, Haynes BF, Polis $M A$, Haase AT, Feinberg MB, Sullivan JL, et al: Changes in thymic function with age and during the treatment of HIV infection. Nature 1998, 396:690-695.

44. Zeng M, Haase AT, Schacker TW: Lymphoid tissue structure and HIV-1 infection: life or death for T cells. Trends Immunol 2012, 33:306-314.

45. Zeng M, Smith AJ, Wietgrefe SW, Southern PJ, Schacker TW, Reilly CS, Estes $J D$, Burton GF, Silvestri G, Lifson JD, et al: Cumulative mechanisms of lymphoid tissue fibrosis and T cell depletion in HIV-1 and SIV infections. J Clin Invest 2011, 121:998-1008.

46. Estes JD, Wietgrefe S, Schacker T, Southern P, Beilman G, Reilly C, Milush JM, Lifson JD, Sodora DL, Carlis JV, Haase AT: Simian immunodeficiency virusinduced lymphatic tissue fibrosis is mediated by transforming growth factor beta 1-positive regulatory $T$ cells and begins in early infection. $J$ Infect Dis 2007, 195:551-561.

47. Tabb B, Morcock DR, Trubey CM, Quinones OA, Hao XP, Smedley J, Macallister R, Piatak M Jr, Harris LD, Paiardini M, et al: Reduced inflammation and lymphoid tissue immunopathology in rhesus macaques receiving anti-tumor necrosis factor treatment during primary simian immunodeficiency virus infection. J Infect Dis 2013, 207:880-892.

48. Schacker TW, Brenchley JM, Beilman GJ, Reilly C, Pambuccian SE, Taylor J, Skarda D, Larson M, Douek DC, Haase AT: Lymphatic tissue fibrosis is associated with reduced numbers of naive CD4+ T cells in human immunodeficiency virus type 1 infection. Clin Vaccine Immunol 2006, 13:556-560.

49. Zeng M, Southern PJ, Reilly CS, Beilman GJ, Chipman JG, Schacker TW, Haase AT: Lymphoid tissue damage in HIV-1 infection depletes naive T 
cells and limits $\mathrm{T}$ cell reconstitution after antiretroviral therapy. PLoS Pathog 2012, 8:e1002437.

50. Hunt PW, Martin JN, Sinclair E, Bredt B, Hagos E, Lampiris H, Deeks SG: $T$ cell activation is associated with lower CD4+ $T$ cell gains in human immunodeficiency virus-infected patients with sustained viral suppression during antiretroviral therapy. J Infect Dis 2003, 187:1534-1543.

51. Lederman MM, Calabrese L, Funderburg NT, Clagett B, Medvik K, Bonilla H, Gripshover B, Salata RA, Taege A, Lisgaris M, et al: Immunologic failure despite suppressive antiretroviral therapy is related to activation and turnover of memory CD4 cells. J Infect Dis 2011, 204:1217-1226.

52. Alter MJ: Epidemiology of viral hepatitis and HIV co-infection. $J$ Hepatol 2006, 44:56-S9.

53. Thio CL, Seaberg EC, Skolasky R Jr, Phair J, Visscher B, Munoz A, Thomas DL: HIV-1, hepatitis B virus, and risk of liver-related mortality in the Multicenter Cohort Study (MACS). Lancet 2002, 360:1921-1926.

54. Fischer MJ, Wyatt CM, Gordon K, Gibert CL, Brown ST, Rimland D, Rodriguez-Barradas MC, Justice AC, Parikh CR: Hepatitis $C$ and the risk of kidney disease and mortality in veterans with HIV. J Acquir Immune Defic Syndr 2010, 53:222-226.

55. Wyatt CM, Malvestutto C, Coca SG, Klotman PE, Parikh CR: The impact of hepatitis $C$ virus coinfection on HIV-related kidney disease: a systematic review and meta-analysis. AIDS 2008, 22:1799-1807.

56. Freiberg MS, Chang CC, Skanderson M, McGinnis K, Kuller LH, Kraemer KL, Rimland D, Goetz MB, Butt AA, Rodriguez Barradas MC, et al: The risk of incident coronary heart disease among veterans with and without HIV and hepatitis C. Circ Cardiovasc Qual Outcomes 2011, 4:425-432.

57. Giordano TP, Kramer JR, Souchek J, Richardson P, El-Serag HB: Cirrhosis and hepatocellular carcinoma in HIV-infected veterans with and without the hepatitis C virus: a cohort study, 1992-2001. Arch Intern Med 2004, 164:2349-2354.

58. Mooij SH, van der Klis FR, van der Sande MA, Schepp RM, Speksnijder AG, Bogaards JA, de Melker HE, de Vries HJ, Snijders PJ, van der Loeff MF: Seroepidemiology of High-Risk HPV in HIV-Negative and HIV-Infected MSM: The H2M Study. Cancer Epidemiol Biomarkers Prev 2013, 22:1698-1708.

59. Palmer JG, Scholefield JH, Coates PJ, Shepherd NA, Jass JR, Crawford LV, Northover JM: Anal cancer and human papillomaviruses. Dis Colon Rectum 1989, 32:1016-1022.

60. Munoz N, Castellsague X, de Gonzalez AB, Gissmann L: Chapter 1: HPV in the etiology of human cancer. Vaccine 2006, 24(Suppl 3):S3/1-10.

61. Neuhaus J, Jacobs DR Jr, Baker JV, Calmy A, Duprez D, La Rosa A, Kuller LH, Pett SL, Ristola M, Ross MJ, et al: Markers of inflammation, coagulation, and renal function are elevated in adults with HIV infection. J Infect Dis 2010, 201:1788-1795.

62. Armah KA, McGinnis K, Baker J, Gibert C, Butt AA, Bryant KJ, Goetz M, Tracy R, Oursler KK, Rimland D, et al: HIV status, burden of comorbid disease, and biomarkers of inflammation, altered coagulation, and monocyte activation. Clin Infect Dis 2012, 55:126-136.

63. Saves M, Chene G, Ducimetiere P, Leport C, Le Moal G, Amouyel P, Arveiler D, Ruidavets JB, Reynes J, Bingham A, Raffi F: Risk factors for coronary heart disease in patients treated for human immunodeficiency virus infection compared with the general population. Clin Infect Dis 2003, 37:292-298.

64. Triant VA, Lee H, Hadigan C, Grinspoon SK: Increased acute myocardial infarction rates and cardiovascular risk factors among patients with human immunodeficiency virus disease. J Clin Endocrinol Metab 2007, 92:2506-2512

65. Goulet JL, Fultz SL, Rimland D, Butt A, Gibert C, Rodriguez-Barradas M, Bryant K, Justice AC: Aging and infectious diseases: do patterns of comorbidity vary by HIV status, age, and HIV severity? Clin Infect Dis 2007, 45:1593-1601.

66. Cockerham L, Scherzer R, Zolopa A, Rimland D, Lewis CE, Bacchetti P, Grunfeld C, Shlipak M, Tien PC: Association of HIV infection, demographic and cardiovascular risk factors with all-cause mortality in the recent HAART era. J Acquir Immune Defic Syndr 2010, 53:102-106.

67. Bergersen BM, Sandvik L, Dunlop O, Birkeland K, Bruun JN: Prevalence of hypertension in HIV-positive patients on highly active retroviral therapy (HAART) compared with HAART-naive and HIV-negative controls: results from a Norwegian study of 721 patients. Eur I Clin Microbiol Infect Dis 2003, 22:731-736.
68. Helleberg M, Afzal S, Kronborg G, Larsen CS, Pedersen G, Pedersen C, Gerstoft J, Nordestgaard BG, Obel N: Mortality attributable to smoking among HIV-1-infected individuals: a nationwide, population-based cohort study. Clin Infect Dis 2013, 56:727-734.

69. Pereyra F, Lo J, Triant VA, Wei J, Buzon MJ, Fitch KV, Hwang J, Campbell JH, Burdo TH, Williams KC, et al: Increased coronary atherosclerosis and immune activation in HIV-1 elite controllers. AIDS 2012, 26:2409-2412.

70. Hsue PY, Hunt PW, Schnell A, Kalapus SC, Hoh R, Ganz P, Martin JN, Deeks SG: Role of viral replication, antiretroviral therapy, and immunodeficiency in HIV-associated atherosclerosis. AIDS 2009, 23:1059-1067.

71. Libby P, Ridker PM, Maseri A: Inflammation and atherosclerosis. Circulation 2002, 105:1135-1143.

72. Ross R: Atherosclerosis-an inflammatory disease. N Engl J Med 1999, 340:115-126.

73. Coussens LM, Werb Z: Inflammation and cancer. Nature 2002, 420:860-867.

74. Grivennikov SI, Greten FR, Karin M: Immunity, inflammation, and cancer. Cell 2010, 140:883-899

75. Bataller R, Brenner DA: Liver fibrosis. J Clin Invest 2005, 115:209-218.

76. Hernandez-Gea V, Friedman SL: Pathogenesis of liver fibrosis. Annu Rev Pathol 2011, 6:425-456.

77. Kaptoge S, Di Angelantonio E, Lowe G, Pepys MB, Thompson SG, Collins R, Danesh J: C-reactive protein concentration and risk of coronary heart disease, stroke, and mortality: an individual participant meta-analysis. Lancet 2010, 375:132-140.

78. Danesh J, Kaptoge S, Mann AG, Sarwar N, Wood A, Angleman SB, Wensley F, Higgins JP, Lennon L, Eiriksdottir G, et al: Long-term interleukin-6 levels and subsequent risk of coronary heart disease: two new prospective studies and a systematic review. PLoS Med 2008, 5:e78.

79. Danesh J, Whincup P, Walker M, Lennon L, Thomson A, Appleby P, Rumley A, Lowe GD: Fibrin D-dimer and coronary heart disease: prospective study and meta-analysis. Circulation 2001, 103:2323-2327.

80. Danesh J, Lewington S, Thompson SG, Lowe GD, Collins R, Kostis JB, Wilson $A C$, Folsom AR, Wu K, Benderly $M$, et al: Plasma fibrinogen level and the risk of major cardiovascular diseases and nonvascular mortality: an individual participant meta-analysis. JAMA 2005, 294:1799-1809.

81. Il'yasova D, Colbert $L H$, Harris TB, Newman AB, Bauer DC, Satterfield $S$, Kritchevsky SB: Circulating levels of inflammatory markers and cancer risk in the health aging and body composition cohort. Cancer Epidemiol Biomarkers Prev 2005, 14:2413-2418.

82. Siemes C, Visser LE, Coebergh JW, Splinter TA, Witteman JC, Uitterlinden AG, Hofman A, Pols HA, Stricker BH: C-reactive protein levels, variation in the C-reactive protein gene, and cancer risk: the Rotterdam Study. J Clin Oncol 2006, 24:5216-5222.

83. Heikkila K, Harris R, Lowe G, Rumley A, Yarnell J, Gallacher J, Ben-Shlomo Y, Ebrahim S, Lawlor DA: Associations of circulating C-reactive protein and interleukin-6 with cancer risk: findings from two prospective cohorts and a meta-analysis. Cancer Causes Control 2009, 20:15-26.

84. Harris TB, Ferrucci L, Tracy RP, Corti MC, Wacholder S, Ettinger WH Jr, Heimovitz $\mathrm{H}$, Cohen HJ, Wallace R: Associations of elevated interleukin-6 and C-reactive protein levels with mortality in the elderly. Am J Med 1999, 106:506-512.

85. Cohen HJ, Harris T, Pieper CF: Coagulation and activation of inflammatory pathways in the development of functional decline and mortality in the elderly. Am J Med 2003, 114:180-187.

86. Shorr AF, Thomas SJ, Alkins SA, Fitzpatrick TM, Ling GS: D-dimer correlates with proinflammatory cytokine levels and outcomes in critically ill patients. Chest 2002, 121:1262-1268.

87. Valdez H, Connick E, Smith KY, Lederman MM, Bosch RJ, Kim RS, St Clair M, Kuritzkes DR, Kessler H, Fox L, et al: Limited immune restoration after 3 years' suppression of HIV-1 replication in patients with moderately advanced disease. AIDS 2002, 16:1859-1866.

88. Kuller LH, Tracy R, Belloso W, De Wit S, Drummond F, Lane HC, Ledergerber B, Lundgren J, Neuhaus J, Nixon D, et al: Inflammatory and coagulation biomarkers and mortality in patients with HIV infection. PLOS Med 2008, 5:e203.

89. Tien PC, Choi Al, Zolopa AR, Benson C, Tracy R, Scherzer R, Bacchetti P, Shlipak M, Grunfeld C: Inflammation and mortality in HIV-infected adults: analysis of the FRAM study cohort. J Acquir Immune Defic Syndr 2010, 55:316-322. 
90. Andrade BB, Hullsiek KH, Boulware DR, Rupert A, French MA, Ruxrungtham K, Montes ML, Price H, Barreiro P, Audsley J, et al: Biomarkers of inflammation and coagulation are associated with mortality and hepatitis flares in persons coinfected with HIV and hepatitis viruses. $J$ Infect Dis 2013, 207:1379-1388.

91. Sandler NG, Wand H, Roque A, Law M, Nason MC, Nixon DE, Pedersen C, Ruxrungtham K, Lewin SR, Emery S, et al: Plasma levels of soluble CD14 independently predict mortality in HIV infection. J Infect Dis 2011, 203:780-790.

92. Hunt PW, Cao HL, Muzoora C, Ssewanyana I, Bennett J, Emenyonu N, Kembabazi A, Neilands TB, Bangsberg DR, Deeks SG, Martin JN: Impact of CD8+ T-cell activation on CD4+ T-cell recovery and mortality in HIV-infected Ugandans initiating antiretroviral therapy. AIDS 2011 25:2123-2131.

93. Duprez DA, Neuhaus J, Kuller LH, Tracy R, Belloso W, De Wit S, Drummond F, Lane HC, Ledergerber B, Lundgren J, et al: Inflammation, coagulation and cardiovascular disease in HIV-infected individuals. PLoS One 2012, 7:e44454.

94. Ford ES, Greenwald JH, Richterman AG, Rupert A, Dutcher L, Badralmaa Y, Natarajan V, Rehm C, Hadigan C, Sereti I: Traditional risk factors and Ddimer predict incident cardiovascular disease events in chronic HIV infection. AIDS 2010, 24:1509-1517.

95. Borges AH, Silverberg MJ, Wentworth D, Grulich AE, Fatkenheuer G, Mitsuyasu R, Tambussi G, Sabin CA, Neaton JD, Lundgren JD: Predicting risk of cancer during HIV infection: the role of inflammatory and coagulation biomarkers. AIDS 2013, 27:1433-1441

96. McComsey GA, Kitch D, Sax PE, Tierney C, Jahed NC, Melbourne K, Ha B, Brown TT, Bloom A, Fedarko N, Daar ES: Associations of Inflammatory Markers with AIDS and non-AIDS Clinical Events after Initiation of Antiretroviral Therapy: AIDS Clinical Trials Group A5224s, a substudy of ACTG A5202. J Acquir Immune Defic Syndr 2013: . Epub.

97. Havlir DV, Bassett R, Levitan D, Gilbert P, Tebas P, Collier AC, Hirsch MS, Ignacio C, Condra J, Gunthard HF, et al: Prevalence and predictive value of intermittent viremia with combination hiv therapy. JAMA 2001, 286:171-179.

98. Grennan JT, Loutfy MR, Su D, Harrigan PR, Cooper C, Klein M, Machouf N, Montaner JS, Rourke S, Tsoukas C, et al: Magnitude of virologic blips is associated with a higher risk for virologic rebound in HIV-infected individuals: a recurrent events analysis. J Infect Dis 2012, 205:1230-1238.

99. Mavigner M, Delobel P, Cazabat M, Dubois M, L'Faqihi-Olive FE, Raymond S, Pasquier C, Marchou B, Massip P, Izopet J: HIV-1 residual viremia correlates with persistent T-cell activation in poor immunological responders to combination antiretroviral therapy. PLoS One 2009, 4:e7658.

100. Wittkop L, Bitard J, Lazaro E, Neau D, Bonnet F, Mercie P, Dupon M, Hessamfar M, Ventura M, Malvy D, et al: Effect of cytomegalovirus-induced immune response, self antigen-induced immune response, and microbial translocation on chronic immune activation in successfully treated HIV type 1-infected patients: the ANRS CO3 Aquitaine Cohort. J Infect Dis 2013, 207:622-627.

101. van de Berg PJ, Heutinck KM, Raabe R, Minnee RC, Young SL, van Donselaar-van der Pant KA, Bemelman FJ, van Lier RA, ten Berge IJ: Human cytomegalovirus induces systemic immune activation characterized by a type 1 cytokine signature. J Infect Dis 2010, 202:690-699.

102. Hsue PY, Hunt PW, Sinclair E, Bredt B, Franklin A, Killian M, Hoh R, Martin JN, McCune JM, Waters DD, Deeks SG: Increased carotid intima-media thickness in HIV patients is associated with increased cytomegalovirusspecific T-cell responses. AIDS 2006, 20:2275-2283.

103. Sacre K, Hunt PW, Hsue PY, Maidji E, Martin JN, Deeks SG, Autran B, McCune JM: A role for cytomegalovirus-specific CD4+CX3CR1+ T cells and cytomegalovirus-induced T-cell immunopathology in HIV-associated atherosclerosis. AIDS 2012, 26:805-814.

104. Kovacs A, Al-Harthi L, Christensen S, Mack W, Cohen M, Landay A: CD8+ T cell activation in women coinfected with human immunodeficiency virus type 1 and hepatitis C virus. J Infect Dis 2008, 197:1402-1407.

105. Gonzalez VD, Falconer K, Blom KG, Reichard O, Morn B, Laursen AL, Weis N, Alaeus A, Sandberg JK: High levels of chronic immune activation in the Tcell compartments of patients coinfected with hepatitis $C$ virus and human immunodeficiency virus type 1 and on highly active antiretroviral therapy are reverted by alpha interferon and ribavirin treatment. J Virol 2009, 83:11407-11411.
106. Estes JD, Harris LD, Klatt NR, Tabb B, Pittaluga S, Paiardini M, Barclay GR, Smedley J, Pung R, Oliveira KM, et al: Damaged intestinal epithelial integrity linked to microbial translocation in pathogenic simian immunodeficiency virus infections. PLOS Pathog 2010, 6:e1001052

107. Pandrea IV, Gautam R, Ribeiro RM, Brenchley JM, Butler IF, Pattison M, Rasmussen T, Marx PA, Silvestri G, Lackner AA, et al: Acute loss of intestinal CD4+ T cells is not predictive of simian immunodeficiency virus virulence. J Immunol 2007, 179:3035-3046.

108. Pandrea I, Gaufin T, Brenchley JM, Gautam R, Monjure C, Gautam A, Coleman C, Lackner AA, Ribeiro RM, Douek DC, Apetrei C: Cutting edge: experimentally induced immune activation in natural hosts of simian immunodeficiency virus induces significant increases in viral replication and CD4+ T cell depletion. J Immunol 2008, 181:6687-6691.

109. Brenchley JM, Price DA, Schacker TW, Asher TE, Silvestri G, Rao S, Kazzaz Z, Bornstein E, Lambotte O, Altmann D, et al: Microbial translocation is a cause of systemic immune activation in chronic HIV infection. Nat Med 2006, 12:1365-1371.

110. Cassol E, Malfeld S, Mahasha P, van der Merwe S, Cassol S, Seebregts C, Alfano M, Poli G, Rossouw T: Persistent microbial translocation and immune activation in HIV-1-infected South Africans receiving combination antiretroviral therapy. J Infect Dis 2010, 202:723-733.

111. Jiang W, Lederman MM, Hunt P, Sieg SF, Haley K, Rodriguez B, Landay A Martin J, Sinclair E, Asher Al, et al: Plasma levels of bacterial DNA correlate with immune activation and the magnitude of immune restoration in persons with antiretroviral-treated HIV infection. J Infect Dis 2009, 199:1177-1185.

112. Funderburg NT, Mayne E, Sieg SF, Asaad R, Jiang W, Kalinowska M, Luciano AA, Stevens W, Rodriguez B, Brenchley JM, et al: Increased tissue factor expression on circulating monocytes in chronic HIV infection: relationship to in vivo coagulation and immune activation. Blood 2010, 115:161-167.

113. Martin DM, Boys CW, Ruf W: Tissue factor: molecular recognition and cofactor function. FASEB J 1995, 9:852-859.

114. Bavinger C, Bendavid E, Niehaus K, Olshen RA, Olkin I, Sundaram V, Wein N, Holodniy M, Hou N, Owens DK, Desai M: Risk of cardiovascular disease from antiretroviral therapy for HIV: a systematic review. PLoS One 2013, 8:e59551.

115. Mocroft A, Phillips AN, Gatell J, Horban A, Ledergerber B, Zilmer K, Jevtovic D, Maltez F, Podlekareva D, Lundgren JD: CD4 cell count and viral load-specific rates of AIDS, non-AIDS and deaths according to current antiretroviral use. AIDS 2013, 27:907-918.

116. Weber R, Sabin CA, Friis-Moller N, Reiss P, El-Sadr WM, Kirk O, Dabis F, Law MG, Pradier C, De Wit S, et al: Liver-related deaths in persons infected with the human immunodeficiency virus: the D:A:D study. Arch Intern Med 2006, 166:1632-1641.

117. Mocroft A, Soriano V, Rockstroh J, Reiss P, Kirk O, de Wit S, Gatell J, Clotet B, Phillips AN, Lundgren JD: Is there evidence for an increase in the death rate from liver-related disease in patients with HIV? AIDS 2005, 19:2117-2125

118. Aceti A, Pasquazzi C, Zechini B, De Bac C: Hepatotoxicity development during antiretroviral therapy containing protease inhibitors in patients with HIV: the role of hepatitis B and C virus infection. J Acquir Immune Defic Syndr 2002, 29:41-48.

119. Wit FW, Weverling GJ, Weel J, Jurriaans S, Lange JM: Incidence of and risk factors for severe hepatotoxicity associated with antiretroviral combination therapy. J Infect Dis 2002, 186:23-31.

120. Sulkowski MS, Thomas DL, Chaisson RE, Moore RD: Hepatotoxicity associated with antiretroviral therapy in adults infected with human immunodeficiency virus and the role of hepatitis $C$ or $B$ virus infection. JAMA 2000, 283:74-80

121. Brau N, Salvatore M, Rios-Bedoya CF, Fernandez-Carbia A, Paronetto F, Rodriquez-Orengo JF, Rodriguez-Torres M: Slower fibrosis progression in HIV/HCV-coinfected patients with successful HIV suppression using antiretroviral therapy. J Hepatol 2006, 44:47-55.

122. Qurishi N, Kreuzberg C, Luchters G, Effenberger W, Kupfer B, Sauerbruch T, Rockstroh JK, Spengler U: Effect of antiretroviral therapy on liver-related mortality in patients with HIV and hepatitis $C$ virus coinfection. Lancet 2003, 362:1708-1713.

123. Kovari H, Sabin CA, Ledergerber B, Ryom L, Worm SW, Smith C, Phillips A, Reiss P, Fontas E, Petoumenos K, et al: Antiretroviral drug-related liver mortality among HIV-positive persons in the absence of hepatitis B or C 
virus coinfection: the data collection on adverse events of anti-HIV drugs study. Clin Infect Dis 2013, 56:870-879.

124. Kalayjian RC, Lau B, Mechekano RN, Crane HM, Rodriguez B, Salata RA, Krishnasami Z, Willig JH, Martin JN, Moore RD, et al: Risk factors for chronic kidney disease in a large cohort of HIV-1 infected individuals initiating antiretroviral therapy in routine care. AIDS 2012, 26:1907-1915.

125. Choi Al, Shlipak MG, Hunt PW, Martin JN, Deeks SG: HIV-infected persons continue to lose kidney function despite successful antiretroviral therapy. AIDS 2009, 23:2143-2149.

126. Cooper RD, Wiebe N, Smith N, Keiser P, Naicker S, Tonelli M: Systematic review and meta-analysis: renal safety of tenofovir disoproxil fumarate in HIV-infected patients. Clin Infect Dis 2010, 51:496-505.

127. Abrams D, Levy Y, Losso MH, Babiker A, Collins G, Cooper DA, Darbyshire J, Emery S, Fox L, Gordin F, et al: Interleukin-2 therapy in patients with HIV infection. N Engl J Med 2009, 361:1548-1559.

128. Emery S, Neuhaus JA, Phillips AN, Babiker A, Cohen CJ, Gatell JM, Girard PM, Grund B, Law M, Losso MH, et al: Major clinical outcomes in antiretroviral therapy (ART)-naive participants and in those not receiving ART at baseline in the SMART study. J Infect Dis 2008, 197:1133-1144.

129. Cohen MS, Chen YQ, McCauley M, Gamble T, Hosseinipour MC, Kumarasamy N, Hakim JG, Kumwenda J, Grinsztejn B, Pilotto JH, et al: Prevention of HIV-1 infection with early antiretroviral therapy. N Engl J Med 2011, 365:493-505.

130. Severe P, Juste MA, Ambroise A, Eliacin L, Marchand C, Apollon S, Edwards A, Bang H, Nicotera J, Godfrey C, et al: Early versus standard antiretroviral therapy for HIV-infected adults in Haiti. N Engl J Med 2010, 363:257-265.

131. Sterne JA, May M, Costagliola D, de Wolf F, Phillips AN, Harris R, Funk MJ, Geskus RB, Gill J, Dabis F, et al: Timing of initiation of antiretroviral therapy in AIDS-free HIV-1-infected patients: a collaborative analysis of 18 HIV cohort studies. Lancet 2009, 373:1352-1363.

132. Kitahata MM, Gange SJ, Abraham AG, Merriman B, Saag MS, Justice AC, Hogg RS, Deeks SG, Eron JJ, Brooks JT, et al: Effect of early versus deferred antiretroviral therapy for HIV on survival. N Engl J Med 2009, 360:1815-1826.

133. Lee L: Timing of HAART initiation and clinical outcomes in human immunodeficiency virus type 1 seroconverters. Arch Intern Med 2011, 171:1560-1569.

134. Cain LE, Logan R, Robins JM, Sterne JA, Sabin C, Bansi L, Justice A, Goulet J, van Sighem $A$, de Wolf $F$, et al: When to initiate combined antiretroviral therapy to reduce mortality and AIDS-defining illness in HIV-infected persons in developed countries: an observational study. Ann Intern Med 2011, 154:509-515

135. Keiser O, Anastos K, Schechter M, Balestre E, Myer L, Boulle A, Bangsberg D, Toure $H$, Braitstein $P$, Sprinz $E$, et al: Antiretroviral therapy in resourcelimited settings 1996 to 2006: patient characteristics, treatment regimens and monitoring in sub-Saharan Africa, Asia and Latin America. Trop Med Int Health 2008, 13:870-879.

136. Egger M: Immunodeficiency at the start of combination antiretroviral therapy in low-, middle-and high-income countries. J Acquir Immune Defic Syndr 2013. In press.

137. Sereti I, Dunham RM, Spritzler J, Aga E, Proschan MA, Medvik K, Battaglia CA, Landay AL, Pahwa S, Fischl MA, et al: IL-7 administration drives T cell-cycle entry and expansion in HIV-1 infection. Blood 2009, 113:6304-6314.

138. Levy Y, Lacabaratz C, Weiss L, Viard JP, Goujard C, Lelievre JD, Boue F, Molina JM, Rouzioux C, Avettand-Fenoel V, et al: Enhanced T cell recovery in HIV-1-infected adults through IL-7 treatment. J Clin Invest 2009, 119:997-1007.

139. Hunt PW: Th17, gut, and HIV: therapeutic implications. Curr Opin HIV and AIDS 2010, 5:189-193.

140. Kanwar B, Favre D, McCune JM: Th17 and regulatory T cells: implications for AIDS pathogenesis. Curr Opin HIV and AIDS 2010, 5:151-157.

141. Macias-Barragan J, Sandoval-Rodriguez A, Navarro-Partida J, ArmendarizBorunda J: The multifaceted role of pirfenidone and its novel targets. Fibrogenesis Tissue Repair 2010, 3:16.

142. Plaeger SF, Collins BS, Musib R, Deeks SG, Read S, Embry A: Immune activation in the pathogenesis of treated chronic HIV disease: a workshop summary. AIDS Res Hum Retroviruses 2012, 28:469-477.

143. Kim S, Iwao H: Molecular and cellular mechanisms of angiotensin II-mediated cardiovascular and renal diseases. Pharmacol Rev 2000 52:11-34
144. Abbas G, Silveira MG, Lindor KD: Hepatic fibrosis and the reninangiotensin system. Am J Ther 2011, 18:e202-e208.

145. Petoumenos K, Worm S, Reiss P, de Wit S, d'Arminio Monforte A, Sabin C, Friis-Moller N, Weber R, Mercie P, Pradier C, et al: Rates of cardiovascular disease following smoking cessation in patients with HIV infection: results from the D:A:D study(*). HIV Med 2011, 12:412-421.

146. EACS Guidelines. http://www.eacsociety.org/Portals/0/Guidelines_Online_ 131014.pdf.

147. Dube MP, Stein JH, Aberg JA, Fichtenbaum CJ, Gerber JG, Tashima KT, Henry WK, Currier JS, Sprecher D, Glesby MJ: Guidelines for the evaluation and management of dyslipidemia in human immunodeficiency virus (HIV)-infected adults receiving antiretroviral therapy: recommendations of the HIV Medical Association of the Infectious Disease Society of America and the Adult AIDS Clinical Trials Group. Clin Infect Dis 2003, 37:613-627.

148. Friis-Moller N, Thiebaut R, Reiss P, Weber R, Monforte AD, De Wit S, El-Sadr W, Fontas E, Worm S, Kirk O, et al: Predicting the risk of cardiovascular disease in HIV-infected patients: the data collection on adverse effects of anti-HIV drugs study. Eur J Cardiovasc Prev Rehabil 2010, 17:491-501.

149. Reinsch N, Neuhaus K, Esser S, Potthoff A, Hower M, Mostardt S, Neumann A, Brockmeyer NH, Gelbrich G, Erbel R, Neumann T: Are HIV patients undertreated? Cardiovascular risk factors in HIV: results of the HIV-HEART study. Eur J Prev Cardiol 2012, 19:267-274.

150. Lundgren JD, Battegay M, Behrens G, De Wit S, Guaraldi G, Katlama C, Martinez E, Nair D, Powderly WG, Reiss P, et al: European AIDS Clinical Society (EACS) guidelines on the prevention and management of metabolic diseases in HIV. HIV Med 2008, 9:72-81.

151. Melzi S, Carenzi L, Cossu MV, Passerini S, Capetti A, Rizzardini G: Lipid Metabolism and Cardiovascular Risk in HIV-1 Infection and HAART: Present and Future Problems. Cholesterol 2010, 2010:271504.

152. Madruga JR, Cassetti I, Suleiman JM, Etzel A, Zhong L, Holmes CB, Cheng AK, Enejosa J, Study ET: The safety and efficacy of switching stavudine to tenofovir df in combination with lamivudine and efavirenz in hiv-1infected patients: three-year follow-up after switching therapy. HIV Clin Trials 2007, 8:381-390.

153. Negredo E, Cruz L, Paredes R, Ruiz L, Fumaz CR, Bonjoch A, Gel S, Tuldra A Balague M, Johnston S, et al: Virological, immunological, and clinical impact of switching from protease inhibitors to nevirapine or to efavirenz in patients with human immunodeficiency virus infection and long-lasting viral suppression. Clin Infect Dis 2002, 34:504-510.

154. Soriano V, Garcia-Gasco P, Vispo E, Ruiz-Sancho A, Blanco F, MartinCarbonero L, Rodriguez-Novoa S, Morello J, de Mendoza C, Rivas P, et al: Efficacy and safety of replacing lopinavir with atazanavir in HIV-infected patients with undetectable plasma viraemia: final results of the SLOAT trial. J Antimicrob Chemother 2008, 61:200-205

155. Mallolas J, Podzamczer D, Milinkovic A, Domingo P, Clotet B, Ribera E, Gutierrez F, Knobel H, Cosin J, Ferrer E, et al: Efficacy and safety of switching from boosted lopinavir to boosted atazanavir in patients with virological suppression receiving a LPV/r-containing HAART: the ATAZIP study. J Acquir Immune Defic Syndr 2009, 51:29-36.

156. Gatell J, Salmon-Ceron D, Lazzarin A, Van Wijngaerden E, Antunes F, Leen C, Horban A, Wirtz V, Odeshoo L, Van den Dungen M, et al: Efficacy and safety of atazanavir-based highly active antiretroviral therapy in patients with virologic suppression switched from a stable, boosted or unboosted protease inhibitor treatment regimen: the SWAN Study (Al424-097) 48-week results. Clin Infect Dis 2007, 44:1484-1492

157. Colafigli M, Di Giambenedetto S, Bracciale L, Tamburrini E, Cauda R, De Luca A: Cardiovascular risk score change in HIV-1-infected patients switched to an atazanavir-based combination antiretroviral regimen. HIV Med 2008, 9:172-179.

158. Eron JJ, Young B, Cooper DA, Youle M, Dejesus E, Andrade-Villanueva J, Workman C, Zajdenverg R, Fatkenheuer G, Berger DS, et al: Switch to a raltegravir-based regimen versus continuation of a lopinavir-ritonavirbased regimen in stable HIV-infected patients with suppressed viraemia (SWITCHMRK 1 and 2): two multicentre, double-blind, randomised controlled trials. Lancet 2010, 375:396-407.

159. Martinez E, Larrousse M, Llibre JM, Gutierrez F, Saumoy M, Antela A, Knobel $H$, Murillas J, Berenguer J, Pich J, et al: Substitution of raltegravir for ritonavir-boosted protease inhibitors in HIV-infected patients: the SPIRAL study. AIDS 2010, 24:1697-1707. 
160. Masia M, Martinez E, Padilla S, Gatell JM, Gutierrez F: Endothelial function in HIV-infected patients switching from a boosted protease inhibitor-based regimen to raltegravir: a substudy of the SPIRAL study. J Antimicrob Chemother 2013, 68:409-413.

161. Gandhi RT, Zheng L, Bosch RJ, Chan ES, Margolis DM, Read S, Kallungal B, Palmer S, Medvik K, Lederman MM, et al: The effect of raltegravir intensification on low-level residual viremia in HIV-infected patients on antiretroviral therapy: a randomized controlled trial. PLOS Med 2010, 7:8.

162. Hatano H, Hayes TL, Dahl V, Sinclair E, Lee TH, Hoh R, Lampiris H, Hunt PW Palmer S, McCune JM, et al: A randomized, controlled trial of raltegravir intensification in antiretroviral-treated, HIV-infected patients with a suboptimal CD4+ T cell response. J Infect Dis 2011, 203:960-968.

163. Yukl SA, Shergill AK, McQuaid K, Gianella S, Lampiris H, Hare CB, Pandori M, Sinclair $E$, Gunthard HF, Fischer M, et al: Effect of raltegravir-containing intensification on HIV burden and T-cell activation in multiple gut sites of HIV-positive adults on suppressive antiretroviral therapy. AIDS 2010, 24:2451-2460.

164. Dahl V, Lee E, Peterson J, Spudich SS, Leppla I, Sinclair E, Fuchs D, Palmer S, Price RW: Raltegravir treatment intensification does not alter cerebrospinal fluid HIV-1 infection or immunoactivation in subjects on suppressive therapy. J Infect Dis 2011, 204:1936-1945.

165. Llibre JM, Buzon MJ, Massanella M, Esteve A, Dahl V, Puertas MC, Domingo P, Gatell JM, Larrouse M, Gutierrez M, et al: Treatment intensification with raltegravir in subjects with sustained HIV-1 viraemia suppression: a randomized 48-week study. Antivir Ther 2012, 17:355-364.

166. Vallejo A, Gutierrez C, Hernandez-Novoa B, Diaz L, Madrid N, AbadFernandez M, Dronda F, Perez-Elias MJ, Zamora J, Munoz E, et al: The effect of intensification with raltegravir on the HIV-1 reservoir of latently infected memory CD4 T cells in suppressed patients. AIDS 2012, 26:1885-1894.

167. Byakwaga H, Kelly M, Purcell DF, French MA, Amin J, Lewin SR, Haskelberg $H$, Kelleher AD, Garsia R, Boyd MA, et al: Intensification of antiretroviral therapy with raltegravir or addition of hyperimmune bovine colostrum in HIV-infected patients with suboptimal CD4+ T-cell response: a randomized controlled trial. J Infect Dis 2011, 204:1532-1540.

168. Hatano H, Strain MC, Scherzer R, Bacchetti P, Wentworth D, Hoh R, Martin JN, McCune JM, Neaton JD, Tracy RP, et al: Increase in 2-LTR Circles and Decrease in D-dimer After Raltegravir Intensification in Treated HIV-Infected Patients: A Randomized: Placebo-Controlled Trial. J Infect Dis 2013, 208(9):1436-1442.

169. Massanella M, Negredo E, Puig J, Puertas MC, Buzon MJ, Perez-Alvarez N, Carrillo J, Clotet B, Martinez-Picado J, Blanco J: Raltegravir intensification shows differing effects on CD8 and CD4 T cells in HIV-infected HAART-suppressed individuals with poor CD4 T-cell recovery. AIDS 2012, 26:2285-2293.

170. Buzon MJ, Massanella M, Llibre JM, Esteve A, Dahl V, Puertas MC, Gatell JM, Domingo P, Paredes R, Sharkey M, et al: HIV-1 replication and immune dynamics are affected by raltegravir intensification of HAART-suppressed subjects. Nat Med 2010, 16:460-465.

171. Cuzin L, Trabelsi S, Delobel P, Barbuat C, Reynes J, Allavena C, Peytavin G, Ghosn J, Lascoux-Combe C, Psomas C, et al: Maraviroc intensification of stable antiviral therapy in HIV-1-infected patients with poor immune restoration: MARIMUNO-ANRS 145 study. J Acquir Immune Defic Syndr 2012, 61:557-564.

172. Wilkin TJ, Lalama CM, McKinnon J, Gandhi RT, Lin N, Landay A, Ribaudo H, Fox L, Currier JS, Mellors JW, et al: A pilot trial of adding maraviroc to suppressive antiretroviral therapy for suboptimal CD4+ T-cell recovery despite sustained virologic suppression: ACTG A5256. J Infect Dis 2012, 206:534-542.

173. Gutierrez C, Diaz L, Vallejo A, Hernandez-Novoa B, Abad M, Madrid N, Dahl $V$, Rubio $R$, Moreno AM, Dronda F, et al: Intensification of antiretroviral therapy with a CCR5 antagonist in patients with chronic HIV-1 infection: effect on T cells latently infected. PLoS One 2011, 6:e27864.

174. Hunt PW, Shulman NS, Hayes TL, Dahl V, Somsouk M, Funderburg NT, McLaughlin B, Landay AL, Adeyemi O, Gilman LE, et al: The immunologic effects of maraviroc intensification in treated HIV-infected individuals with incomplete CD4+ T-cell recovery: a randomized trial. Blood 2013, 121:4635-4646.

175. Berenguer J, Alvarez-Pellicer J, Martin PM, Lopez-Aldeguer J, Von-Wichmann MA, Quereda C, Mallolas J, Sanz J, Tural C, Bellon JM, Gonzalez-Garcia J:
Sustained virological response to interferon plus ribavirin reduces liver-related complications and mortality in patients coinfected with human immunodeficiency virus and hepatitis C virus. Hepatology 2009, 50:407-413.

176. Berenguer J, Rodriguez E, Miralles P, Von Wichmann MA, Lopez-Aldeguer J, Mallolas J, Galindo MJ, Van Den Eynde E, Tellez MJ, Quereda C, et al: Sustained virological response to interferon plus ribavirin reduces non-liver-related mortality in patients coinfected with HIV and Hepatitis C virus. Clin Infect Dis 2012, 55:728-736.

177. Jennings $C L$, Sherman KE: Hepatitis $C$ and HIV co-infection: new drugs in practice and in the pipeline. Curr HIV/AIDS Rep 2012, 9:231-237.

178. Hunt PW, Martin JN, Sinclair E, Epling L, Teague J, Jacobson MA, Tracy RP, Corey L, Deeks SG: Valganciclovir reduces T cell activation in HIV-infected individuals with incomplete CD4+ T cell recovery on antiretroviral therapy. J Infect Dis 2011, 203:1474-1483.

179. Yi TJ, Walmsley S, Szadkowski L, Raboud J, Rajwans N, Shannon B, Kumar S, Kain KC, Kaul R, Tan DH: A randomized controlled pilot trial of valacyclovir for attenuating inflammation and immune activation in HIV, HSV-2 coinfected adults on suppressive antiretroviral therapy. Clin Infect Dis 2013, 57(9):1331-1338.

180. Baigent C, Keech A, Kearney PM, Blackwell L, Buck G, Pollicino C, Kirby A, Sourjina T, Peto R, Collins R, Simes R: Efficacy and safety of cholesterollowering treatment: prospective meta-analysis of data from 90,056 participants in 14 randomised trials of statins. Lancet 2005, 366:1267-1278.

181. Jain MK, Ridker PM: Anti-inflammatory effects of statins: clinical evidence and basic mechanisms. Nat Rev Drug Discov 2005, 4:977-987.

182. Aslangul E, Fellahi S, Assoumou LK, Bastard JP, Capeau J, Costagliola D: High-sensitivity C-reactive protein levels fall during statin therapy in HIV-infected patients receiving ritonavir-boosted protease inhibitors. AIDS 2011, 25:1128-1131.

183. De Wit S, Delforge M, Necsoi CV, Clumeck N: Downregulation of CD38 activation markers by atorvastatin in HIV patients with undetectable viral load. AIDS 2011, 25:1332-1333.

184. Ganesan A, Crum-Cianflone N, Higgins J, Qin J, Rehm C, Metcalf J, Brandt C, Vita J, Decker CF, Sklar P, et al: High dose atorvastatin decreases cellular markers of immune activation without affecting HIV-1 RNA levels: results of a double-blind randomized placebo controlled clinical trial. J Infect Dis 2011, 203:756-764.

185. Moore RD, Bartlett JG, Gallant JE: Association between use of HMG CoA reductase inhibitors and mortality in HIV-infected patients. PLOS One 2011, 6:e21843.

186. Overton ET, Kitch D, Benson CA, Hunt PW, Stein JH, Smurzynski M, Ribaudo $H J$, Tebas P: Effect of statin therapy in reducing the risk of serious non-AIDS-defining events and nonaccidental death. Clin Infect Dis 2013, 56:1471-1479.

187. Rasmussen LD, Kronborg G, Larsen CS, Pedersen C, Gerstoft J, Obel N: Statin therapy and mortality in HIV-infected individuals; a Danish nationwide population-based cohort study. PLOS One 2013, 8:e52828.

188. Ben-Zvi I, Kivity S, Langevitz P, Shoenfeld Y: Hydroxychloroquine: from malaria to autoimmunity. Clin Rev Allergy Immunol 2012, 42:145-153.

189. Savarino A, Gennero L, Sperber K, Boelaert JR: The anti-HIV-1 activity of chloroquine. J Clin Virol 2001, 20:131-135.

190. Sperber K, Chiang G, Chen H, Ross W, Chusid E, Gonchar M, Chow R, Liriano O: Comparison of hydroxychloroquine with zidovudine in asymptomatic patients infected with human immunodeficiency virus type 1. Clin Ther 1997, 19:913-923.

191. Murray SM, Down CM, Boulware DR, Stauffer WM, Cavert WP, Schacker TW Brenchley JM, Douek DC: Reduction of immune activation with chloroquine therapy during chronic HIV infection. J Virol 2010, 84:12082-12086.

192. Paton NI, Goodall RL, Dunn DT, Franzen S, Collaco-Moraes Y, Gazzard BG, Williams IG, Fisher MJ, Winston A, Fox J, et al: Effects of hydroxychloroquine on immune activation and disease progression among HIV-infected patients not receiving antiretroviral therapy: a randomized controlled trial. JAMA 2012, 308:353-361.

193. Piconi S, Parisotto S, Rizzardini G, Passerini S, Terzi R, Argenteri B, Meraviglia $P$, Capetti A, Biasin M, Trabattoni D, Clerici M: Hydroxychloroquine drastically reduces immune activation in HIV-infected, antiretroviral therapy-treated immunologic nonresponders. Blood 2011, 118:3263-3272.

194. Harris SG, Padilla J, Koumas L, Ray D, Phipps RP: Prostaglandins as modulators of immunity. Trends Immunol 2002, 23:144-150. 
195. Pettersen FO, Torheim EA, Dahm AE, Aaberge IS, Lind A, Holm M, Aandahl EM, Sandset PM, Tasken K, Kvale D: An exploratory trial of cyclooxygenase type 2 inhibitor in HIV-1 infection: downregulated immune activation and improved T cell-dependent vaccine responses. J Virol 2011, 85:6557-6566

196. Kvale D, Ormaasen V, Kran AM, Johansson CC, Aukrust P, Aandahl EM, Froland SS, Tasken K: Immune modulatory effects of cyclooxygenase type 2 inhibitors in HIV patients on combination antiretroviral treatment. AIDS 2006, 20:813-820.

197. Cannon CP, Cannon PJ: Physiology. COX-2 inhibitors and cardiovascular risk. Science 2012, 336:1386-1387.

198. Baigent C, Blackwell L, Collins R, Emberson J, Godwin J, Peto R, Buring J, Hennekens C, Kearney P, Meade T, et al: Aspirin in the primary and secondary prevention of vascular disease: collaborative meta-analysis of individual participant data from randomised trials. Lancet 2009, 373:1849-1860.

199. O'Brien M, Montenont E, Hu L, Nardi MA, Valdes V, Merolla M, Gettenberg G, Cavanagh K, Aberg JA, Bhardwaj N, Berger JS: Aspirin attenuates platelet activation and immune activation in HIV-1-infected subjects on antiretroviral therapy: a pilot study. J Acquir Immune Defic Syndr 2013, 63:280-288.

200. Read SW, DeGrezia M, Ciccone EJ, DerSimonian R, Higgins J, Adelsberger JW, Starling JM, Rehm C, Sereti I: The effect of leflunomide on cycling and activation of T-cells in HIV-1-infected participants. PLoS One 2010, 5:e11937.

201. Andrieu JM, Lu W: Long-term clinical, immunologic and virologic impact of glucocorticoids on the chronic phase of HIV infection. BMC Med 2004 2:17.

202. Ulmer A, Muller M, Bertisch-Mollenhoff B, Frietsch B: Low dose prednisolone reduces CD4+ T cell loss in therapy-naive HIV-patients without antiretroviral therapy. Eur J Med Res 2005, 10:105-109.

203. McComsey GA, Whalen CC, Mawhorter SD, Asaad R, Valdez H, Patki AH, Klaumunzner J, Gopalakrishna KV, Calabrese LH, Lederman MM: Placebo-controlled trial of prednisone in advanced HIV-1 infection. AIDS 2001, 15:321-327.

204. Wallis RS, Kalayjian R, Jacobson JM, Fox L, Purdue L, Shikuma CM, Arakaki R, Snyder S, Coombs RW, Bosch RJ, et al: A study of the immunology, virology, and safety of prednisone in HIV-1-infected subjects with CD4 cell counts of 200 to $700 \mathrm{~mm}^{3}$. J Acquir Immune Defic Syndr 2003, 32:281-286

205. Da Silva JA, Jacobs JW, Kirwan JR, Boers M, Saag KG, Ines LB, de Koning EJ, Buttgereit F, Cutolo M, Capell H, et al: Safety of low dose glucocorticoid treatment in rheumatoid arthritis: published evidence and prospective trial data. Ann Rheum Dis 2006, 65:285-293.

206. Miller KD, Masur H, Jones EC, Joe GO, Rick ME, Kelly GG, Mican JM, Liu S, Gerber LH, Blackwelder WC, et al: High prevalence of osteonecrosis of the femoral head in HIV-infected adults. Ann Intern Med 2002, 137:17-25.

207. Gori A, Tincati C, Rizzardini G, Torti C, Quirino T, Haarman M, Ben Amor K, van Schaik J, Vriesema A, Knol J, et al: Early impairment of gut function and gut flora supporting a role for alteration of gastrointestinal mucosa in human immunodeficiency virus pathogenesis. J Clin Microbiol 2008, 46:757-758

208. Roberfroid M: Prebiotics: the concept revisited. J Nutr 2007, 137:830S-837S.

209. Sanders ME: Probiotics: definition, sources, selection, and uses. Clin Infect Dis 2008, 46(Suppl 2):S58-S61.

210. Gori A, Rizzardini G, Van't Land B, Amor KB, van Schaik J, Torti C, Quirino T, Tincati C, Bandera A, Knol J, et al: Specific prebiotics modulate gut microbiota and immune activation in HAART-naive HIV-infected adults: results of the "COPA" pilot randomized trial. Mucosal Immunol 2011, 4:554-563.

211. Irvine SL, Hummelen R, Hekmat S, Looman CW, Habbema JD, Reid G: Probiotic yogurt consumption is associated with an increase of CD4 count among people living with HIV/AIDS. J Clin Gastroenterol 2010, 44:e201-e205.

212. Gonzalez-Hernandez LA, Jave-Suarez LF, Fafutis-Morris M, Montes-Salcedo KE, Valle-Gutierrez LG, Campos-Loza AE, Enciso-Gomez LF, AndradeVillanueva JF: Synbiotic therapy decreases microbial translocation and inflammation and improves immunological status in HIV-infected patients: a double-blind randomized controlled pilot trial. Nutr J 2012 11:90.
213. Schunter M, Chu H, Hayes TL, McConnell D, Crawford SS, Luciw PA, Bengmark S, Asmuth DM, Brown J, Bevins CL, et al: Randomized pilot trial of a synbiotic dietary supplement in chronic HIV-1 infection. BMC Complement Altern Med 2012, 12:84.

214. Floren CH, Chinenye S, Elfstrand L, Hagman C, Ihse I: ColoPlus, a new product based on bovine colostrum, alleviates HIV-associated diarrhoea. Scand J Gastroenterol 2006, 41:682-686.

215. Plettenberg A, Stoehr A, Stellbrink HJ, Albrecht H, Meigel W: A preparation from bovine colostrum in the treatment of HIV-positive patients with chronic diarrhea. Clin Investig 1993, 71:42-45.

216. Rump JA, Arndt R, Arnold A, Bendick C, Dichtelmuller H, Franke M, Helm EB, Jager H, Kampmann B, Kolb P, et al: Treatment of diarrhoea in human immunodeficiency virus-infected patients with immunoglobulins from bovine colostrum. Clin Investig 1992, 70:588-594.

217. Jiang ZD, DuPont HL: Rifaximin: in vitro and in vivo antibacterial activity-a review. Chemotherapy 2005, 51(Suppl 1):67-72.

218. Festi D, Mazzella G, Orsini M, Sottili S, Sangermano A, Li Bassi S, Parini P, Ferrieri A, Falcucci M, Grossi L: Rifaximin in the treatment of chronic hepatic encephalopathy; results of a multicenter study of efficacy and safety. Curr Ther Res 1993, 54:598-609.

219. Bass NM, Mullen KD, Sanyal A, Poordad F, Neff G, Leevy CB, Sigal S, Sheikh MY, Beavers K, Frederick T, et al: Rifaximin treatment in hepatic encephalopathy. N Engl J Med 2010, 362:1071-1081.

220. Ambizas EM, Ginzburg R: Lubiprostone: a chloride channel activator for treatment of chronic constipation. Ann Pharmacother 2007, 41:957-964

221. Moeser AJ, Nighot PK, Engelke K, Ueno R, Blikslager AT: Recovery of mucosal barrier function in ischemic porcine ileum and colon is stimulated by a novel agonist of the CIC-2 chloride channel, lubiprostone. Am J Physiol Gastrointest Liver Physiol 2007, 292:G647-G656.

222. Manns B, Stevens L, Miskulin D, Owen WF Jr, Winkelmayer WC, Tonelli M: A systematic review of sevelamer in ESRD and an analysis of its potential economic impact in Canada and the United States. Kidney Int 2004, 66:1239-1247

223. Stinghen AE, Goncalves SM, Bucharles S, Branco FS, Gruber B, Hauser AB, Pecoits-Filho R: Sevelamer decreases systemic inflammation in parallel to a reduction in endotoxemia. Blood Purif 2010, 29:352-356.

224. Navarro-Gonzalez JF, Mora-Fernandez C, Muros de Fuentes M, DonateCorrea J, Cazana-Perez V, Garcia-Perez J: Effect of phosphate binders on serum inflammatory profile, soluble CD14, and endotoxin levels in hemodialysis patients. Clin J Am Soc Nephrol 2011, 6:2272-2279.

225. Burger D, Travis S: Conventional medical management of inflammatory bowel disease. Gastroenterology 2011, 140:1827-1837. e1822.

doi:10.1186/1742-6405-10-29

Cite this article as: Hsu et al:: Serious Non-AIDS events:

Immunopathogenesis and interventional strategies. AIDS Research and Therapy 2013 10:29.

\section{Submit your next manuscript to BioMed Central and take full advantage of:}

- Convenient online submission

- Thorough peer review

- No space constraints or color figure charges

- Immediate publication on acceptance

- Inclusion in PubMed, CAS, Scopus and Google Scholar

- Research which is freely available for redistribution 